Article

\title{
Social Representations of Natural Hazard Risk in Swiss Mountain Regions
}

\author{
Elisabeth Maidl 1,2,* and Matthias Buchecker ${ }^{1}$ \\ 1 Research Unit Economics and Social Sciences, Swiss Federal Research Institute WSL, Zürcherstrasse 111, \\ CH-8903 Birmensdorf, Switzerland; matthias.buchecker@wsl.ch \\ 2 School of Business, University of Applied Sciences and Arts Northwestern FHNW, Riggenbachstrasse 16, \\ CH-4600 Olten, Switzerland \\ * Correspondence: elisabeth.maidl@wsl.ch; Tel.: +41-62-957-2875
}

Received: 15 November 2018; Accepted: 13 December 2018; Published: 20 December 2018

check for updates

\begin{abstract}
The term "risk" is connoted with divergent meanings in natural hazard risk research and the practice of risk management. Whilst the technical definition is accurately defined, in practice, the term "risk" is often synonymously used with "danger". Considering this divergence as a deficiency, risk communication often aims to correct laypersons' understanding. We suggest to instead treat the variety of meanings as a resource for risk communication strategies. However, there is however to date no investigation of what laypersons' meanings of risk actually comprise. To address this gap, we examine the meanings of risk by applying a social representations approach within a qualitative case study research design. Results of the study among inhabitants of Swiss mountain villages show that differences in meanings were found according to hazard experience and community size. We found commonly shared core representations and peripheral ones. We conclude with suggestions on how to make usage of the knowledge on SR in risk communication.
\end{abstract}

Keywords: social representations; natural hazard risk; qualitative risk research; risk communication; Alpine hazards; risk management

\section{Introduction}

Research on natural hazard risks showed that risk prevention requires consideration of subjective aspects [1-3]. Individual risk awareness and preparedness are acknowledged key parameters in the integrated risk management paradigm [4]. Considerable efforts have been made in recent years to determine the (individual) influence factors of these parameters such as concern, knowledge, trust or experience [2,3,5-7]. The empirical results are, however, not fully consistent, which is mainly due to specific research designs and operationalizations of the parameters that reveal distinct aspects of the phenomenon [8]. This diversity of research designs is based on specific understandings of hazard risks, acknowledging that these understandings cover a diverse range of aspects [9]. Research on divergent meanings of hazard risks that scientists, survey respondents, interview partners and practitioners have in mind, is scarce $[9,10]$. The goal of this study was to explore laypersons' meanings of hazard risks using a social representation approach. Joffe [1] firstly examined natural hazard risk as social representation and concluded in her review that the meaning of risk depended on social, emotional and symbolic, respectively cultural circumstances. Her findings were further developed by Breakwell [11,12], who investigated the link between social representations and identity to draw conclusions on risk communication. There are currently no systematic empirical investigations on the content and scope of laypersons' and experts' social representations of natural hazard risks. With our study, we provide the first such study and outline how our findings can be used for risk research and 
the practice of risk communication. Before focusing on risk meanings based on social representations, we will give an overview on how laypersons' notion of risk has been conceived in risk research.

\section{Literature Review}

\subsection{Laypersons' Notion of Risk}

There is no consensus among scientists about the definition of risk but it is mostly defined as a product of probability and possible damage $[9,13]$. This natural scientific expert definition is central to risk management but may be in conflict with laypersons' intuitive understanding of risk [1]. Research on social aspects of risks was for a long time dominated by psychometric approaches, that is based on a positivistic perspective and focuses on biasing factors of laypersons' risk perception. Representative of this approach traced quantitative differences in people's assessment of a variety of risks back to the characteristics of the risks themselves, assuming that risk perceptions were determined by universal cognitive structures [14]) and affective reactions [15]. Risk according to this approach is an objective fact that laypersons fail to conceive accurately, due to universal mechanisms of distortion. In contrast to these individual focused assumptions, empirical studies revealed that laypersons' assessment of risks differed depending on their residential locations and their individual and collective experiences with disasters [8,16-18].

In the last decades, several studies abandoned the idea of objectivity in understanding risks, instead adopting a constructivist approach [19-21]. Accordingly, understandings of risks and problems are formed according to the relationships between relevant social groups and between individuals and institutions [22]. This is also reflected in the role that trust has been found to have on risk perception and risk prevention $[23,24]$. Moreover, recent studies have revealed that social vulnerabilities shape laypersons' risk perception and that that their perception of specific risks strongly depends on the perceived consequences of the risks for their livelihoods [21,25,26]. From this perspective, hazard risks have to be understood in their interaction with other (more) relevant aspects of people's lives, such as their social belonging, their livelihood or their religion $[1,10,27,28]$. This approach also places more emphasis on the role of local risk communication, community engagement and related learning processes for risk interpretation [29,30]. Furthermore, the literature on social learning provides evidence that actors' problem or risk perspectives, which are framed by specific interests, can be reframed through participatory processes/collective actions towards shared problem or risk understandings $[30,31]$. Accordingly, active social communities can be expected to have shared social representations of hazard risks that are achieved not just through similar experiences but also through their communication over a long period of time [30]. There is, however, little empirical knowledge on how laypersons make sense of risk and hazard and how they influence each other in their social and institutional context [10].

\subsection{Social Representations of Risk and Risk Communication}

In risk communication, the divergence of meanings is treated as a failure to be overcome. In this study, we are particularly interested in these differences, which we consider relevant, because integrated risk management depends on stakeholders' active participation, which can only be established through a meaningful discourse based on stakeholders' understanding of risk [32].

Prior studies tend to rely on experts' definitions of risk. For instance, in the context of Switzerland, the studies of Siegrist and Gutscher [33,34] measure citizens' attitudes and willingness to take preventive action in reference to experts' definition as represented in official hazard risk maps. This approach pays attention to the gap between both but does not further investigate laypersons' understanding.

In traditional communities characterized by highly interdependent livelihoods, knowledge is constituted and shared through experience and social interaction [35]; in such contexts risks are considered as (more or less relevant) aspects of livelihoods and community life [1]. In the field of 
risk communication, it is necessary to regard the local context in which knowledge is generated and shared. In more fragmented communities, problem understandings of actors are, according to the mental model approach, expected to diverge as a result of selective, interest focused interpretation of information [31,36,37]. Accordingly, risk area residents were found to vary in the degree they differentiated mental models of environmental hazards [38] or cognitive maps of flood zones [39]. Similarly, the Faultline theory suggests a split of such communities in subgroups based on the group members' demographic alignment [40]. Lindell and Perry [29] suspect in their discussion of the protective action decision model that people's prevention behaviour might be more determined by such group-specific interests than by their risk perception. Recent research provides evidence that two-way communication, in particular in bottom-up problem solving processes, enable a convergence of actors' problem perspectives and an increase of locals' trust in experts [41-44]. It is, however, unclear to what extent the framing or re-framing of problem perspectives affects local laypersons' general notions of risk, resp. hazards. To investigate this in sufficient depth, we used a research approach based on the theory of social representations [45].

According to Moscovici, society is a source of meaning, which we share, create and reproduce inter-subjectively. Social representations are systems of communication and social influences that constitute social realities [45]. To examine social reality shared in natural hazard risk management, we included both citizens' and experts' perspectives and how they make sense of risks.

Social representations serve not only as the principal means for the generation of meanings but also knowledge, identities and practices. By the act of sharing, a system of inclusion and exclusion of these shared understandings are established [45]. We consider SRT therefore to reveal valuable insights for risk communication. Information that is isolated from the identities and practices of the audience's life world could not be effective. Applying Breakwell's [11] concept of risk communication, we define it as "new information [that] must be presented in such a way as to be consistent with the levels of understanding $(\ldots)$ that is manifest in the audience."

Understanding processes of inter-subjective construction of reality is useful for strategies in risk communication [11]. Breakwell suggests to first analyse social representations as a pre-requisite for developing effective communication strategies according to the following steps, which we consider in our research design.

- Description of social representations.

- Classification of social representation types: hegemonic, emancipated or polemical.

- Identification of core and periphery social representations

- Reflection of which social representations are target of change by communication.

As a further assumption for the present study, the term "risk" in everyday life is synonymous with the term "danger". Our focus is on what "risk" generally and in particular natural hazard risks mean to inhabitants in dwellings that are frequently or potentially prone to natural hazards in mountain regions in Switzerland.

With this explorative empirical examination, we aim to provide a better understanding of risk awareness and behaviour as social capacities under local conditions. The examination of the content and scope of shared meanings in respect of natural hazard risks helps to better understand public opinions formation and by that, what the conditions for risk communication strategies are. We do not assume that laypersons think in a wrong way as according to the deficit model of communication [46]. Instead, laypersons' social representations provide a base for planning and implementation of strategies that anchor the integrated risk management paradigm in real-life risk management procedures.

Figure 1 illustrates how a natural hazard event is processed in a community's collective consciousness. First, the event occurs and is attributed with meanings that are available within this community. The attribution determines the meaning of the event, for instance fate, god's punishment, a case to be managed, nature's revenge or a spectacle for example. The meaning that gets anchored in the collective consciousness is the most hegemonic one. Thereby, the event functions 
to preserve meanings and values that constitute identity in a community. In the case that there is no available meaning, this is a chance to create a new representation, which will also have an effect on identity formation.

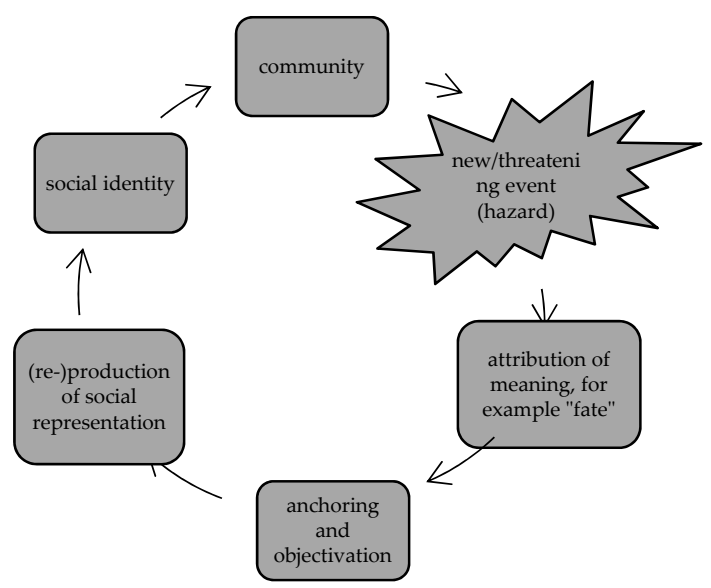

Figure 1. Emergence of social representation (own illustriation according to [46]).

When a phenomenon like a flood is first encountered or the impact of a flood breaks available social representations, there may be several interpretations. Over time, by selection and rationalization, each society, community or social group constructs a certain meaning of historical events that will be taken forward within the collective consciousness [45].

This also applies for the meaning of historical hazard events, like a historic rock fall event in the 19th century in the community of Felsberg (see results section). The collective memory is present in the local community, described with the same words and formulations and part of local identity. In contrast, the more recent rock fall event from the 1990s is less homogenously ascribed with meaning. Investigating the topic of collective memory, Halbwachs [47] interprets commonly shared beliefs as a memory process rather than ascription of current meanings. Memories of natural hazard events can be examined as objectively observable entities. Some particular memories in communities are taken forward, others not. The preserved memories are a base for comparison and ascription of meaning for current events.

\subsection{Overview of $S R T$}

The origins of SRT go back to Durkheim [48]. The term "collective representation" was introduced by him to describe stable traditional patterns that structure society. Based on this, Moscovici [45] developed the term "social representation" that is more suitable to describe the change of such structures. It focuses on how meanings are constructed within and between social groups. A social representation as outcome is a set of believes and at the same time a process in which such believes are formed, on which decision-making and action is oriented. Social representations serve to establish a social order that enables individuals to make sense of the world they live in and enable communication among members by sharing meaning.

Applying this to the topic of natural hazard risks allows the investigation of a commonly shared core or peripheral fragmented meanings that are relevant in risk management. Sharing is to take over and internalize certain meanings, whereas others fade away. The process of internalization is called "anchoring" in SRT. New information is anchored into pre-existing patterns of worldview and an individual's role in it. Behaviour is not only influenced by internalizing social representations from the external world but also identity. The matter of identity within a community influences the adaptivity of social systems and is a relevant factor for change in natural hazard risk management. Identity as a community member is a basis for participation in local discourse [49]. Wagner points out that individuals do not attain representations by cognitive processes or personal experience but by 
connecting them with those of others. Core social representations correspond to generalized other and essential values. Therefore, the degree of congruence of one's own thoughts with the generalized other results in a social position at the core of a community.

A second principle of social representation is called "objectification". It is the process of making abstract anchored meanings concrete in daily life. In other words, in contrast to anchoring, something internal is objective in the outside world. Shared meanings are attributed to particular phenomena and expressed as such. This happens in social interactions and in every communication, for example, talking to neighbours is a contribution to the construction of meanings.

The scope of meanings comprises core elements and peripheral elements [50]. The core-in Abric's terms "noyeau central" - contains the stable meaning of social representations, used most commonly and spontaneously within a community or cultural group. At the periphery, meanings are rather subject to change. They are expressed less spontaneously and only by more individualized persons. From the periphery, new interpretations can be integrated in the construction of reality and renew the existing set of believes.

Social representations mirror the manifold meanings, which emerge from the diversity of subjectively and culturally shaped perceptions. Since, according to the individualization thesis [51], perceptions, meanings and identities are more and more fragmented and therefore the overlap of commonly shared meanings becomes narrower. Accordingly, lifestyle and social environment are subject to choice from a broad set of options. Since individuals internalize many representations in mixed contexts, there can be a certain variety of different meanings within a community [49]. For instance, the same hazard event in a village does not necessarily have the same meaning for all residents but there is one meaning that is the norm from which others deviate.

Moscovici [45] distinguishes between three types of social representations: hegemonic, emancipated and polemical ones. The first is at the stable core and commonly shared. Emancipated social representations emerge from particularly shared meanings within sub-groups of a community. They are a source of innovation as they are compatible with core social representation. Polemical representation, however appear to not be acceptable and are rejected, resp. subject to conflict.

\section{Materials and Methods}

\subsection{Research Questions and Method}

Our general aim is to provide a better understanding of enhancing or challenging conditions for the implementation of integrated risk management. In the particular focus of this study on SR of risk, our guiding research questions are:

1. What does risk mean to inhabitants in areas prone to natural hazards?

2. How can knowledge about SR be used for risk communication?

To address these questions, we use a qualitative case study method with application of SRT. The qualitative approach is indicated by asking questions like "why" and "how" different meanings of risk, related attitudes and behaviours emerge within a particular common context. This hermeneutic investigation of how meaning is socially constructed is methodologically rooted in phenomenological theory. In phenomenology it is argued that certainty is only possible within experience of the world [52] and therefore, research needs to focus on experience within consciousness, rather than investigate phenomena separate from the meaning they have in people's social context. The hermeneutic method's logic is to integrate and start from meanings and practices in lived experiences [53].

Taking the perspective of SRT, we address this experience by conducting interviews with inhabitants and local risk managers in mountain villages, that is, members of the local communities (see Table 1).

Since our approach is explorative, we make use of grounded theory [54]. Grounded theory is an inductive methodology, that is, data is collected as material to develop new theoretical assumptions, 
instead of vice versa, applying theory to data. In our case, the aim is not to develop a whole theory but results, on which conclusions are drawn for conceptual hypotheses about how risk communication needs to integrate the way people create meaning, attitudes and behaviours towards natural hazard risk.

The research design of the case study refers to Yin's [55] recommendation to use a multiple case study design for the investigation of phenomena in their everyday context, where boundaries between this context and the phenomenon are fluid. The case study focuses on a low number of data points and a larger number of variables, which is a setting not suitable for a quantitative research design. The sources of information in this study are the qualitative, semi-structured interviews. According to the logic of hermeneutic research, the interviews serve as units for intensive analysis, with the goal of revealing the scope of contents of meanings. The content-based exploration of the focal research units allows understand of a larger class of units, that is, members of local communities prone to natural hazard risk.

According to Yin [55], an integrative case study design requires the choice of cases that are embedded in a common context. In this case, the canton of Grisons. Within the common institutional and cultural cantonal context, we chose two regions and within the regions, the cases of single communities. The comparability between the cases is given by the common context and further common criteria regarding size and organization of the communities. The common background allows characteristics, in which the communities differ from each other, to be contrasted. These contrasting characteristics relate to local conditions in terms of natural hazard risks: time elapsed since the last hazard experience, development of local hazard risk management procedures and strategies and type of hazard risk (e.g., rock fall, flood or avalanche).

\subsection{Case Study Description}

The common institutional context in the canton of Grisons is given by cantonal risk management. Risk management in Grisons is currently adopting the integrative risk management approach and is establishing comparable structures of risk management in the different regions and communities. To enhance this, local actors are involved in official risk management. The goal is to better mitigate natural hazard risks that concerns around $10 \%$ of all buildings in the canton.

With risk management initiatives launched within the last decade, the canton provides an interesting field for studying natural hazard risk management. In 2010, the Cantonal Building Insurance initiated the program GRIP. GRIP stands for risk analysis, intervention and prevention. The aim of the program was to standardize local risk management strategies according to canton-wide criteria and thereby foster integrated risk management in all municipalities [56,57]. The program was first run as a pilot project in the communities of Domat-Ems and Felsberg in the Imboden region. The Imboden region is the core region for the case study and supplemented with interviews in the region of Inn.

The units of analysis are the following communities nested within two regions (Table 1). An overview of all interviewees is given in the Appendix A. 
Table 1. Overview case study regions.

\begin{tabular}{|c|c|c|c|}
\hline Region & Communities & Interview Partners & $\begin{array}{c}\text { Additional Information on Interview } \\
\text { Partner }\end{array}$ \\
\hline \multirow{29}{*}{ R1 Imboden } & \multirow{9}{*}{ C1 Felsberg } & R1C1_I1: municipal secretary & \multirow{3}{*}{$\begin{array}{c}\text { M, LCC } \\
\text { F, house owner close to red zone } \\
\text { F, garden outside community border in red } \\
\text { zone }\end{array}$} \\
\hline & & R1C1_I2: gardener & \\
\hline & & R1C1_I3: gardener & \\
\hline & & R1C1_I4: priest & M, LCC \\
\hline & & R1C1_I5: major & F, LCC \\
\hline & & R1C1_I6: district forester & M, LCC \\
\hline & & R1C1_I7: local entrepreneur & $\mathrm{F}$, runs guest house \\
\hline & & R1C1_I8: resident & $\begin{array}{l}\text { M, involved in cantonal hazard risk } \\
\text { management }\end{array}$ \\
\hline & & $\begin{array}{l}\text { R1C1_I9: local historian (m) } \\
\text { R1C1 I10: resident (m) }\end{array}$ & $\begin{array}{c}\text { M, source of information on community } \\
\text { M, regional entrepreneur }\end{array}$ \\
\hline & \multirow{5}{*}{$\begin{array}{l}\text { C2 Domat-Ems } \\
\text { (regional capital) }\end{array}$} & R1C2 I1: municipal secretary & $M$ I $C R$ \\
\hline & & R1C2_I2: major & F, LCC \\
\hline & & $\begin{array}{l}\text { R1C2_I3: fire brigade } \\
\text { commander }\end{array}$ & M, LCC \\
\hline & & R1C2_I4: district forester & \multirow{2}{*}{$\begin{array}{c}\text { M, LCC } \\
\text { M, knowledge of community surrounding } \\
\text { nature }\end{array}$} \\
\hline & & R1C2_I5: hunter & \\
\hline & \multirow{8}{*}{ C3 Tamins } & R1C3_I1: municipal secretary & \multirow{4}{*}{$\begin{array}{c}\text { M, LCC } \\
\text { F, farmer, no hazard experience } \\
\text { F, elderly resident, lived in community } \\
\text { whole life } \\
\text { M, family father }\end{array}$} \\
\hline & & R1C3_I2: resident1 & \\
\hline & & R1C3_I3: resident2 & \\
\hline & & R1C3_I4: resident3 & \\
\hline & & $\begin{array}{l}\text { R1C3_I5: fire brigade } \\
\text { commander }\end{array}$ & M, LCC \\
\hline & & R1C3_I6: farmer1 & $\begin{array}{l}\text { M, recent hazard experience, located at the } \\
\text { community border close to blue risk zone }\end{array}$ \\
\hline & & $\begin{array}{l}\text { R1C3_I7: district forester (m, } \\
\text { member of local risk committee) }\end{array}$ & M, LCC \\
\hline & & R1C3_I8: farmer2 & $\begin{array}{l}\text { M, sheep keeper, knowledge of community } \\
\text { surrounding nature }\end{array}$ \\
\hline & \multirow{7}{*}{ C4 Flims and Laax } & $\begin{array}{l}\text { R1C3_I1: head of community } \\
\text { construction office }\end{array}$ & M, LCC \\
\hline & & R1C3_I2: restaurant owner & $\mathrm{M}$, interest in tourism \\
\hline & & R1C3_I3: merchant & $\mathrm{M}$, interest in tourism \\
\hline & & $\begin{array}{l}\text { R1C3_I4: former fire brigade } \\
\text { commander }\end{array}$ & $\mathrm{M}$, experience in local risk management \\
\hline & & R1C3_I5: district forester & M, LCC \\
\hline & & R1C3_I6: free rider & $\begin{array}{c}\text { M, knowledge of community surrounding } \\
\text { nature }\end{array}$ \\
\hline & & $\begin{array}{l}\text { R1C3_I7: deputy chief } \\
\text { avalanche rescue }(\mathrm{m})\end{array}$ & M, LCC \\
\hline \multirow{11}{*}{ R2 Inn } & \multirow{7}{*}{ C1 Susch and Ardez } & R2C1_I1: visitor of local clinic & $\begin{array}{l}\text { F. (The clinic permanently has visitors, who } \\
\text { stay for a duration up to several weeks.) }\end{array}$ \\
\hline & & $\begin{array}{c}\text { R2C1_I2: resident } \\
\text { R2C1_I3: municipal secretary }\end{array}$ & $\begin{array}{l}\text { F, resident and young local entrepreneur } \\
\text { M, LCC }\end{array}$ \\
\hline & & R2C1_I4: hunter & $\begin{array}{l}\text { M, knowledge of community surrounding } \\
\text { nature, spent whole life in community }\end{array}$ \\
\hline & & $\begin{array}{l}\text { R2C1_I5: fire brigade } \\
\text { commander }\end{array}$ & M, LCC \\
\hline & & R2C1_I6: major & $\mathrm{M}, \mathrm{LCC}$ \\
\hline & & R2C1_I7: resident & $\mathrm{M}$, retired local railway collaborator \\
\hline & & R2C1_I8: resident & $\mathrm{M}$, house owner risk zone \\
\hline & \multirow{4}{*}{ C2 Scuol } & R2C2_I1: employee tourist office & $\mathrm{F}$, tourist information \\
\hline & & R2C1_I2: civil protection officer & $\mathrm{M}, \mathrm{LCC}$ \\
\hline & & R2C1_I3: resident $(\mathrm{m})$ & M, resident, no hazard experience \\
\hline & & R2C1_I4: tourist (f) & $\mathrm{F}$, touristic visitor for day trip \\
\hline
\end{tabular}

According to theoretical sampling strategy [54], particular communities within the canton were selected. The choice of interview partners was driven by targeted saturation until no new information could be drawn from adding additional interviewees.

We chose communities with and without hazard experience. The latter communities were chosen by the criteria that the last natural hazard event has taken place approximately 10 years ago. This period allows us to examine what immediate reactions and long-term changes are observable under currently non-exceptional conditions and reveal citizens' associations of risk under regular 
circumstances. For contrasting comparison, the community of Tamins was included, to cover the case of a community that was not affected by natural hazards. Further, the cases cover both touristic and non-touristic communities.

To cover a broad scope of backgrounds and perspectives, respondents with different personal and professional backgrounds were selected. In each community, we interviewed actors involved in local risk management: municipality officials, professional civil actors in risk management (e.g., foresters, members of civil protection, technical employee), volunteers like fire fighters, residents within or close to hazard risk zones. Risk zones are defined in national hazard maps. The maps display information on which of the four classes of hazard risk: high danger, that is, red zone, moderate danger, that is, blue zone, low danger, that is, yellow zone and no danger that is, white zone [56].

The first interview in each community was conducted with a community officer, who was contacted in advance by the head of the Cantonal Office for Forest and Natural Hazards to support for the study, resp. the mayor. This served as a starting point in each community to identify further key actors in local natural hazard risk management, both, officials and private persons, who knew the particular communities well, for example, a local historian, a priest and hunters. Among official local risk managers, we interviewed members of the crisis committee, that is, typically the mayor, foresters, head of fire brigade and members of the cantonal civil protection agency. The crisis committees differ from community to community in size and membership. Also, the frequency of committee meetings may vary from once a year to once in 10 years in communities that are seldom affected by hazard events. Additionally, we interviewed local inhabitants who live in or close to a risk zone or have personal hazard experience. Residents were selected as interview partners on-site, for instance a holder of vegetable allotments located in the red hazard risk zone, where the construction of buildings is prohibited but land use for small gardens is allowed.

This principle of targeted saturation was accordingly applied in the other case study communities to ensure retrieval of relevant local information. Altogether 32 interviews were conducted in March and April 2014.

Each community was visited for a stay of one consecutive week. This ensured not only that interview dates with the relevant official actors could be arranged in advance but also for observations on site and talking to locals.

In touristic regions, daily life is characterized by the presence of tourists in the villages. Their view was included by conducting short interviews using the social representations part of the interview guideline. In non-tourist regions, these supplemental short interviews were conducted with locals who were not involved in risk management.

In the first, open part of the interviews, respondents were asked to name free associations for the following terms: risk, nature, danger, natural hazard risk, natural disaster, security, freedom, responsibility, trust, solidarity, and protection measures. We collected free associations with the terms "risk" and "danger" without naming the topic or purpose of the study. Additionally, respondents were asked to provide free associations with other terms related to a general value system, norms and world view, for example, "nature", "responsibility", "freedom" or "solidarity". After this first part of an interviews, people were invited to share their experience and knowledge in semi-structured interviews. Since the focus of this article is on SR of risk only, results of the interviews were used for description of local conditions only.

This part of the interview was transcribed according to a content analysis approach [58]. Based on these transcripts, codes of social representations were derived from interviews in each community. The results focus on social representations. These are compared and discussed in Section 4 of this article. We did additional comparison with the social representations of "danger", since differences in the understanding of both terms are relevant for the practice of risk communication.

The second part of the interviews was conducted according to a semi-structured guideline and served to collect information on local circumstances and to interpret results on social representations 
within the particular context. This part of the interviews is the basis for community descriptions in the results section. The interview material was paraphrased instead of using direct quotations.

The guideline for professionals (e.g., municipality officers) contained questions on socio-demographic characteristics, the organization of local natural hazard risk management, contact and collaboration with other actors, personal and professional background, narration of personal and professional hazard experience, perception of actors' responsibilities, estimation of risk awareness and preparedness in the population and among responsible actors. The guideline for private interviewees included the same questions, except for those related to organization of local risk management.

Potential bias $[58,59]$ in the interview data are addressed as shown in Table 2. The reflection shows that the introduction part of each interview and the free association part, served to avoid certain kinds of bias. Instead of focusing and filtering their answers according to a given research question, interviewees first were guided to open their minds. They were interviewed in a place of their choice (office, home, cafés, outdoor) where they would feel comfortable. A trustful atmosphere was also provided by being present and open for talks during the interviewing period in each community.

Table 2. Potential bias in interviews.

\begin{tabular}{|c|c|c|}
\hline Potential Source of Bias & Description & $\begin{array}{l}\text { Estimated Effect of Such Bias in the } \\
\text { Present Study }\end{array}$ \\
\hline Artificiality & $\begin{array}{l}\text { Interviewees feel forced to invent } \\
\text { an opinion }\end{array}$ & $\begin{array}{l}\text { The second part of the guideline was } \\
\text { applied with officials / professionals only, } \\
\text { that is, expert information on natural } \\
\text { hazards was only asked from experts, not } \\
\text { private inhabitants. }\end{array}$ \\
\hline Lack of trust & $\begin{array}{l}\text { Interviewees might not express } \\
\text { thoughts to complete strangers }\end{array}$ & $\begin{array}{l}\text { By spending several days in each } \\
\text { community, familiarity was provided. }\end{array}$ \\
\hline Lack of time & $\begin{array}{l}\text { Interviewee do not get the chance } \\
\text { to express relevant information }\end{array}$ & $\begin{array}{l}\text { Interview dates were arranged as to } \\
\text { ensure broad time slots. }\end{array}$ \\
\hline Level of entry & $\begin{array}{l}\text { Talking to certain actors might } \\
\text { restrict chances to talk to others. }\end{array}$ & $\begin{array}{l}\text { The first person to be interviewed in a } \\
\text { community acted as a door opener to } \\
\text { other community members and to } \\
\text { establish trust. }\end{array}$ \\
\hline Elite bias & $\begin{array}{l}\text { Researchers might tend to } \\
\text { interview only well-informed } \\
\text { persons of high status in the } \\
\text { particular field }\end{array}$ & $\begin{array}{c}\text { Interview partners were chosen } \\
\text { considering diversity of backgrounds } \\
\text { (experts, less articulate } \\
\text { inhabitants, visitors). }\end{array}$ \\
\hline Construction knowledge & $\begin{array}{c}\text { Interviewers might not realize that } \\
\text { they are also actively constructing } \\
\text { knowledge by } \\
\text { gathering information. }\end{array}$ & $\begin{array}{c}\text { Each interview started with a free } \\
\text { association part that served to open the } \\
\text { interviewees mind. Before the interview } \\
\text { started as little information as possible } \\
\text { was given about the purpose and subject } \\
\text { of the study. } \\
\text { Interviewee's constructions where not a } \\
\text { side effect of interviews but it was } \\
\text { targeted to gather the content of } \\
\text { their constructions. }\end{array}$ \\
\hline Ambiguity of language & $\begin{array}{l}\text { The meaning of what is asked with } \\
\text { a question is often not congruent } \\
\text { with the meaning, interviewees } \\
\text { ascribe to the question. }\end{array}$ & $\begin{array}{l}\text { Since the "free association" part of the } \\
\text { interviews targeted to clarify the scope of } \\
\text { possible meanings of interviewees, there } \\
\text { was no right or wrong understanding of } \\
\text { the question. }\end{array}$ \\
\hline
\end{tabular}

\section{Results}

In this section, we show results from four kinds of communities according to the contrasting characteristics of hazard experience and tourism: (1) recent hazard experience, (2) hazard experience 10 years before, (3) no recent hazard experience and (4) touristic communities. 
In the following sections, we provide a brief description of each community and social representations. The comprehensive transcript of respondent's association with the terms "risk" and "danger", on which the presentation of results is based, is provided in the Appendix A.

\subsection{Communities with Recent Hazard Experience: Domat-Ems and Felsberg}

\subsubsection{Community Description}

The communities of Felsberg and Domat-Ems are located in the region of Imboden, a valley of the Rhine river bordered by the Calanda mountain. Domat-Ems is the regional capital neighbouring the community of Felsberg. Unlike Felsberg, where the last hazard event occurred in 2001, Domat-Ems was affected by a landslide at the nearby Val Parghera in 2013. The landslide destroyed parts of the main traffic route for the community but no assets within the community borders. The residential zone itself is assessed as white risk zone (no risk) but parts of the surrounding areas are located in yellow and red zones (Figures 2 and 3). In the past, heavy rainfalls regularly caused severe landslides and flooding near the dwelling area. An event still present in the respondents' collective memory is an event from 1983, when a local torrent flooded a youth camp causing 6 deaths.

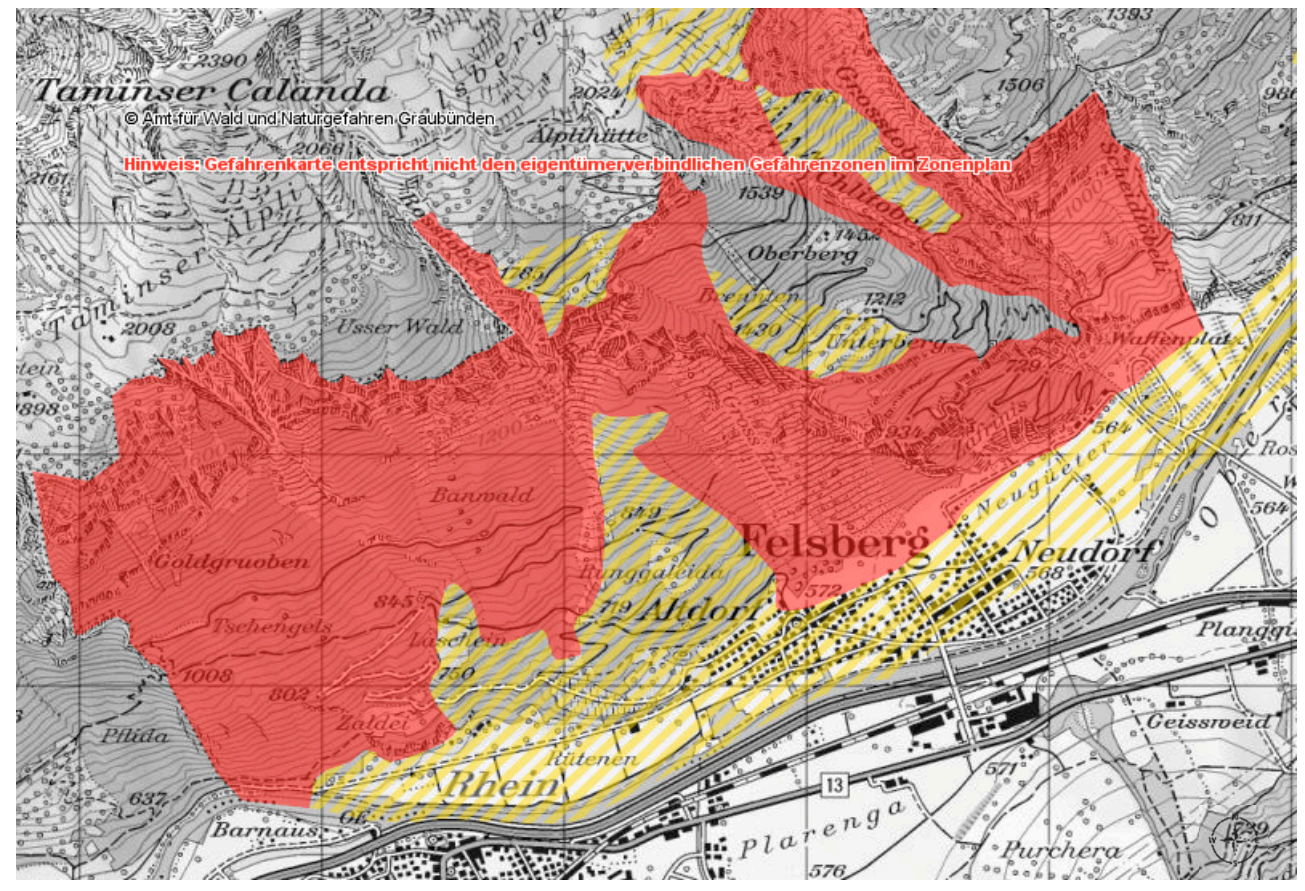

Figure 2. Natural hazard risk map of Domat-Ems: flood risk zones (Latitude: 46.833636 I Longitude: 9.447354; for all following figures: coordinates refer to the location of the community; (C) Canton of Grisons). 


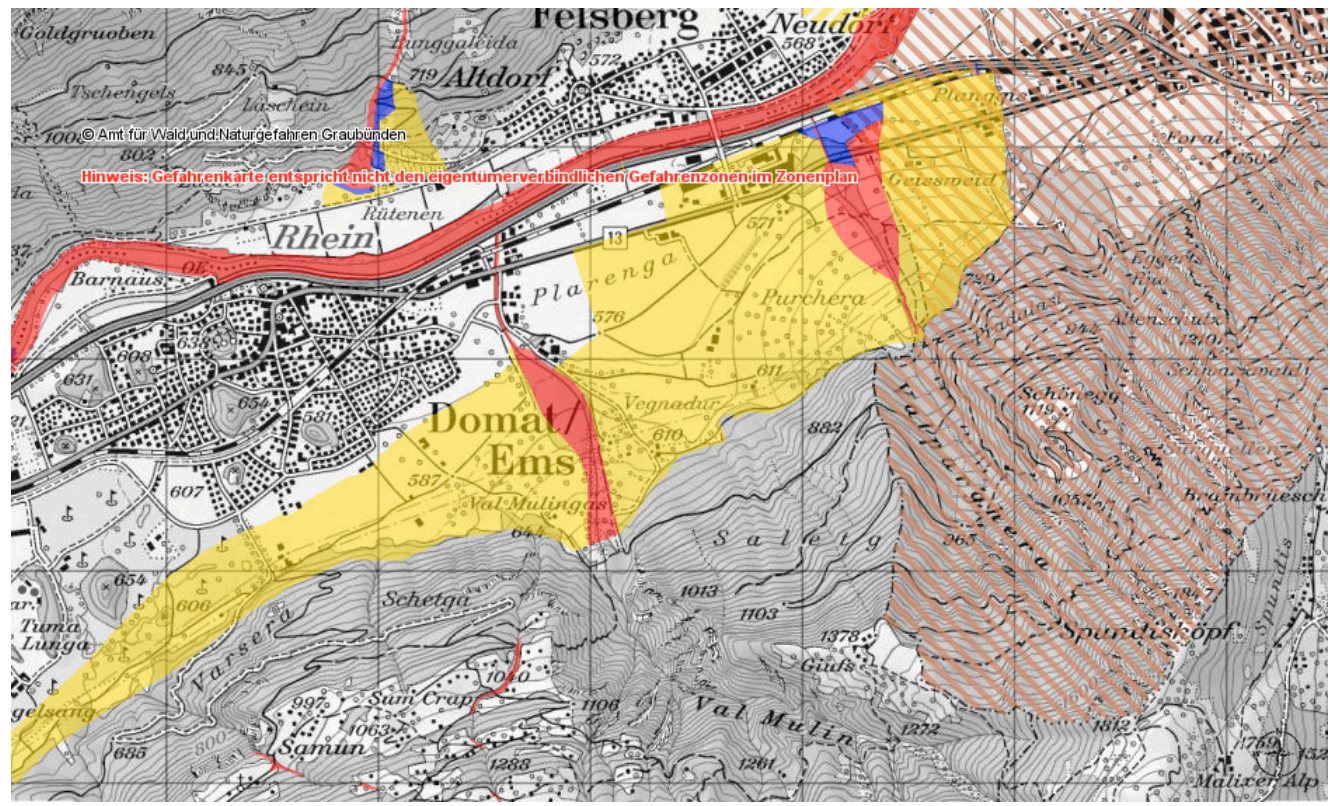

Figure 3. Natural hazard risk map of Felsberg: rock fall risk zones (Latitude: 46.845238 । Longitude: 9.47123; @ Canton of Grisons).

Felsberg is located close to the Calanda limestone rock wall (Figures 2 and 3). After a famous event in 1834, rock falls were subsequently systematically documented. Until 2002, around 50 events were counted [60]. In 2001, the last major event occurred when 250,000 cubic metres of material fell down but did not threaten lives or homes. Within the last decade, floods caused by the river Rhine took place in 2005 and 2009. The whole area of the community lies in the yellow-white rock fall risk zone and the northern community border is located close to the red zone.

\subsubsection{Local Risk Management}

In the last years, cantonal initiatives have been launched to bring local natural hazard risk management up to a common standard and structure, for example, the training of local natural hazard consultants. In 2013, the Cantonal Building Insurance worked out the GRIP project (Grisons Risk analysis, Intervention and Prevention) to improve local risk management [56,57]. The project was started in two pilot municipalities, of which one was Domat-Ems. The landslide at Val Parghera took place in the same year. By that time, the GRIP procedures were not yet established but the community was already elaborating past hazard experience. Since 2013, integrated natural hazard risk management was increasingly a focus in the municipality, for example, by fostering risk dialogue between stakeholders and collaboration with neighbour communities and the Cantonal Office. The information flow was professionalized, regular meetings and risk assessments were established and the population receives weekly information. For communication strategies, the community used cantonal police communication principles as a model, that is, a regular schedule for repeated information and translation of expert language into common language.

Respondents' answers are consistent in the view that the severe flood experience of 2001 resulted in increased awareness of risks and initiatives to better prepare for the future. Before 2001, the community did not have a local crisis committee. Today, the committee conducts exercises every 3 to 4 years. This is an exceptionally high level of activity compared to other communities in the case study.

Interviews showed that respondents consider strong solidarity, trust and active community life a resource in hazard mitigation. However, the view is shared that citizens' participation in the community decreased since community assemblies no longer take place. Instead, information events are offered to the population, which are considered effective as they are a platform for direct dialogue with citizens but participation is rather low. 


\subsubsection{Social Representations}

Residents in Felsberg predominantly understood risk as natural hazard risks, especially rock fall and flood (Tables 1 and 2). The meaning of "risk" is predominantly influenced by a local perspective, which is closely related to the lived environment. Experts and politically responsible actors, in contrast to private actors, highlighted that natural hazard risk was minor compared to other risks the community needs to deal with. Interviewees also expressed a perspective of risks that goes beyond local conditions, namely global climate change. We labelled this as "general perspective" in contrast to the merely local one. Further, the view is commonly shared that risk is manmade and subject to individual responsibility and behaviour. The respondents' associations also revealed that responsibility on the community level is as a matter of spatial planning and structural protection measures. This illustrates a belief in controllability of risks that is rooted in the belief in scientific progress. Another SR is that risks can be controlled by observation and learning. The latter also shows that risk is regarded positively, instead of risk as a potential threat only: society can learn to live with risks and individuals can even take advantage in terms of pleasure by taking risks and making boundary experiences. Accordingly, on a normative level of understanding, respondents claimed that individuals should take responsibility for their actions and political actors should provide guidelines to enhance protection on a group level. Further, the interviewees' statements included normative judgements such as mankind should protect nature, because damage in nature might cause hazards. This is related to the metaphor of nature taking revenge.

Interviews with inhabitants of Felsberg revealed that living with the rock fall risk is part of the community identity. It is a source of pride not to show worry or fear and relate this to the traditional way of the Felsberg people. This pride, however results in a tendency to conceal worry.

In Domat-Ems, results show additional dimensions of understanding risks. In contrast to the neighbour community of Felsberg, citizens in Domat-Ems are not visually confronted with natural hazard. Consequently, their SRs of risk are less natural hazard related. The particularly local perspective on risks is influenced more by the nearby chemical plant and risk caused by traffic. The local officials' SRs show that natural hazard risk protection in this community is understood more as a commonly shared responsibility than a matter of individual behaviour. This is in accordance to the integrated risk management approach to risk management in which communication and information flow are regarded as important and measures were taken to improve it. The importance of sensitization, communication and integration of actors turned out to be a prominent association with the term "risk". Technical personnel, similarly as in other communities, emphasized the controllability of natural hazard risk and described it as a matter of assessment and calculation. In this respect, it is remarkable that technical progress is sometimes doubted as a means of providing better protection in the future. Instead, living in close connection with nature is considered more important, since it enhances the ability to see and understand nature's signals. Furthermore, we found that to the respondents, taking risks meant a trade-off to working efficiently. This is close to the social representation of risks in other communities, where the view is shared that risks are unavoidable and omnipresent.

In comparison with associations to the term "danger", results show that danger stimulates more emotionally connoted answers than the term "risk". A memorable difference is that danger in contrast to risk is highly related with threat. Accordingly, instead of controllability, rather the unpredictable nature of danger is emphasized. Risk was rather regarded as observable. Danger is also viewed more as an expression of the power of nature. This aspect is not only perceived as negative or dreadful but also raised fascination.

The free associations to the term risk and danger were analysed by paraphrasing respondents' answers to codes. These codes are equivalent to types of social representations. The codes summarize expressed thoughts in the respondent's statement as shown in the example of Felsberg (Tables 3 and 4). Tables 2 and 3 show the results on the social representations part of the interview guideline at the example of the community of Felsberg (Showing the tables for all cases would exceed the limits of this paper. In case of interest, please contact the authors.). The codes are numbered according to what 
aspect was named first. So, category 1 shows which kind of association was named first, category 2 shows what was named in the second place and so on. The number of codes depends on how many different aspects of meanings were named overall. In some communities, where natural hazard risks are frequently experienced, more such codes could be extracted from the respondent's answers, which indicates that in such communities, respondent's think more about natural hazards and come up with a greater range of social representations (Tables 4 and 5). In Section 4.5 an overview of all codes is provided. Some of them refer to social life in communities like and social interaction, others to general worldview and nature and some represent individual attitudes.

\subsection{A Community without Hazard Experience: Tamins}

\subsubsection{Community Description}

The community of Tamins is located at the confluence of the two sources of the Rhine River, the Vorderrhein and the Hinterrhein (Figure 4). In the past the region was affected by floods but today constructional measures prevent severe flooding by the Rhine River. According to the natural hazard risk map, the whole community is either marked as a yellow-white or blue rock fall risk zone and in the North, it borders the red rock fall zone. The banks of the local river are blue flood risk zones within the community. The community was chosen as a contrast to neighbouring communities where severe natural hazards occurred within the last couple of years. The last natural hazard event that occurred in Tamins was a small rock fall event in 2013. Only one inhabitant was affected, whose farm is located near the red zone at the edge of the community. Outside the inhabited areas, avalanches and landslides regularly affect forests and meadows. Especially the nearby Kunkel mountain pass regularly needs to be closed down and there are land use restrictions. Among local inhabitants, acceptance for such measures is low.

The community's crisis committee that is structured like in other communities, that is, it is composed of the major, community secretary, the technical community employee and the district forester. However, no meetings or exercises take place and its members are hardly aware of their role or responsibility. 
Table 3. Social representations of risk in Felsberg

\begin{tabular}{|c|c|c|c|c|c|}
\hline \multirow{2}{*}{ Interviewee } & \multirow{2}{*}{ Transcript of Associations with the Term "Risk" } & \multicolumn{4}{|c|}{ Codes of Social Representations Derived from Interviewees' Associations } \\
\hline & & 1 & 2 & 3 & 4 \\
\hline $\begin{array}{l}\text { (1) Community } \\
\text { secretary }(m)\end{array}$ & $\begin{array}{c}\text { Risk is relative to country and community. Further, risk refers to individual } \\
\text { behaviour for example risky sport. } \\
\begin{array}{c}\text { Risk itself is the assessment of danger and measures taken by the community } \\
\text { are based on this assessment. }\end{array}\end{array}$ & Relativity. & Individual behaviour. & Assessment of danger. & - \\
\hline (2) Resident 1 (f) & $\begin{array}{l}\text { Here rock fall is a major risk. } \\
\text { As a community, I would never permit construction so close to the red risk zone. }\end{array}$ & Local perspective. & $\begin{array}{l}\text { Community } \\
\text { responsibility. }\end{array}$ & Land use planning. & - \\
\hline (3) Gardener (f) & $\begin{array}{l}\text { Mankind is craving for power and greedy and exploits nature in all parts of the } \\
\text { world. Switzerland is no exception. Mankind claims too much space for itself } \\
\text { and leaves not enough for animals. This causes danger and risk. }\end{array}$ & Manmade. & General perspective. & Risk $=$ danger & - \\
\hline (4) Priest $(\mathrm{m})$ & $\begin{array}{l}\text { Risk is a matter of learning how to deal with it. Taking risks can also mean } \\
\text { pleasure and making boundary experience. Risks can be managed. Life is risk. }\end{array}$ & Learning. & Boundary experience. & Controllability. & Part of life. \\
\hline (5) Major (f) & $\begin{array}{c}\text { There is always residual risk. Climate change requires individual behaviour } \\
\text { change. }\end{array}$ & Residual risk. & Climate change. & $\begin{array}{l}\text { Individual } \\
\text { responsibility. }\end{array}$ & Controllability \\
\hline (6) District forester (m) & $\begin{array}{l}\text { There are always certain risks but nothing severe. Risk is that something might } \\
\text { happen. Today one can deal with it well. Risk is also a matter of individual } \\
\text { readiness to take risks. }\end{array}$ & Omnipresent. & Control-lability. & $\begin{array}{l}\text { Individual } \\
\text { responsibility. }\end{array}$ & - \\
\hline (7) Entrepreneur (f) & $\begin{array}{l}\text { Risk is a matter of individual assessment. Risk is human. One can decide to take } \\
\text { it or not. Risk is fun for certain people. }\end{array}$ & Assessment. & Human. & Individual decision. & Fun. \\
\hline (8) Resident 2 (m) & $\begin{array}{l}\text { Risk is the danger that something might happen. } \\
\text { In an economic sense it has twofold meaning: positive and negative. }\end{array}$ & Potential danger. & Economy. & $\begin{array}{l}\text { Ambivalence: } \\
\text { positive/negative. }\end{array}$ & - \\
\hline (9) Hobby historian (m) & $\begin{array}{l}\text { Risk is part of life. If nothing happens, people become reckless. There are more } \\
\text { severe risks than natural hazards. }\end{array}$ & Part of life. & Omni-present. & Recklessness. & - \\
\hline (10) Visitor (m) & $\begin{array}{l}\text { Risk is a matter of curiosity. It's individual. Additionally, it's a polarity between } \\
\text { adventure and restraint. }\end{array}$ & Curiosity. & $\begin{array}{l}\text { Individual } \\
\text { responsibility. }\end{array}$ & $\begin{array}{l}\text { Polarity: positive and } \\
\text { negative. }\end{array}$ & - \\
\hline
\end{tabular}


Table 4. Social representation of danger in Felsberg.

\begin{tabular}{|c|c|c|c|c|c|c|c|}
\hline \multirow{2}{*}{ Interviewee } & \multirow{2}{*}{ Transcript of Associations with The Term "Risk" } & \multicolumn{6}{|c|}{ Codes of Social Representations Derived from Interviewees' Associations } \\
\hline & & 1 & 2 & 3 & 4 & 5 & 6 \\
\hline $\begin{array}{l}\text { (1) Community } \\
\text { secretary }(m)\end{array}$ & $\begin{array}{l}\text { Versatility. Danger can come from anywhere, natural hazards but also } \\
\text { traffic, at home. Here in Felsberg, you can see the danger of rock fall but } \\
\text { there is a lot of invisible danger. If you have children with you, } \\
\text { perception changes. }\end{array}$ & Versatility. & Omnipresent. & $\begin{array}{l}\text { Local } \\
\text { perspective. }\end{array}$ & Invisible. & $\begin{array}{l}\text { Responsibility } \\
\text { for others. }\end{array}$ & Threat. \\
\hline (2) Resident 1 (f) & $\begin{array}{l}\text { In Felsberg it is about the Calanda mountain. } 12 \text { years ago, all houses } \\
\text { faced the rock, you could observe it. I wasn't afraid but fascinated. The } \\
\text { unpredictable power of nature made us feel how small we are. Now, our } \\
\text { house and the stable will be demolished and make place for new } \\
\text { buildings for flats. I used to like living here but I would not dare to } \\
\text { construct new buildings so close to the mountain. It could reach the core } \\
\text { of the village. }\end{array}$ & $\begin{array}{l}\text { Local } \\
\text { perspective. }\end{array}$ & Fascination. & Unpredictable. & $\begin{array}{l}\text { Power of } \\
\text { nature. }\end{array}$ & $\begin{array}{l}\text { Land use } \\
\text { planning. }\end{array}$ & Threat. \\
\hline (3) Gardener (f) & $\begin{array}{l}\text { Chemical plant accident, natural hazard and also discontent citizens. It's } \\
\text { tragic that so many people aren't satisfied with what they have. }\end{array}$ & $\begin{array}{l}\text { Industry } \\
\text { accident. }\end{array}$ & - & - & - & - & - \\
\hline (4) Priest $(\mathrm{m})$ & $\begin{array}{l}\text { People in the mountains always face danger. Avalanches, landslides, the } \\
\text { Calanda, the Rhine river. Felsberg ever has been threatened. Further, the } \\
\text { globalized nature is dangerous: environment, climate change, traffic. }\end{array}$ & $\begin{array}{l}\text { Part of life in } \\
\text { mountains. }\end{array}$ & $\begin{array}{l}\text { Local } \\
\text { perspective. }\end{array}$ & $\begin{array}{l}\text { General } \\
\text { perspective: } \\
\text { climate change }\end{array}$ & - & Traffic. & - \\
\hline (5) Major (f) & $\begin{array}{l}\text { Fear of unpredictable things. Generally, climate change, which causes } \\
\text { natural hazards like the landslide at Val Palghera. }\end{array}$ & Un-predictable. & $\begin{array}{l}\text { Local } \\
\text { perspective. }\end{array}$ & $\begin{array}{c}\text { General } \\
\text { perspective: } \\
\text { climate change }\end{array}$ & - & - & - \\
\hline (7) Entrepreneur (f) & $\begin{array}{l}\text { Motorbike but otherwise there is no danger. However, they say there } \\
\text { are wolves. }\end{array}$ & Traffic. & Sports. & Wolves. & - & - & - \\
\hline (8) Resident $2(\mathrm{~m})$ & The negative side of risk. Something that can threaten me. & Threat. & - & - & - & - & - \\
\hline (9) Visitor (m) & Fear, stimulus, threat, death, life instinct. & Threat. & Stimulus. & $\begin{array}{l}\text { Ambiguity: } \\
\text { death and life. }\end{array}$ & - & - & - \\
\hline
\end{tabular}


Table 5. Numbers of codes found.

\begin{tabular}{ccc}
\hline Community & Number of Codes for “Risk" & Number of Codes for “Danger" \\
\hline R1C1 Felsberg & 4 & 6 \\
R1C2 Domat-Ems & 4 & 7 \\
R1C3 Tamins & 3 & 5 \\
R1C1 Flims and Laax & 5 & 5 \\
R2C1 Susch & 4 & 5 \\
R2C2 Scuol & 2 & 4 \\
\hline
\end{tabular}

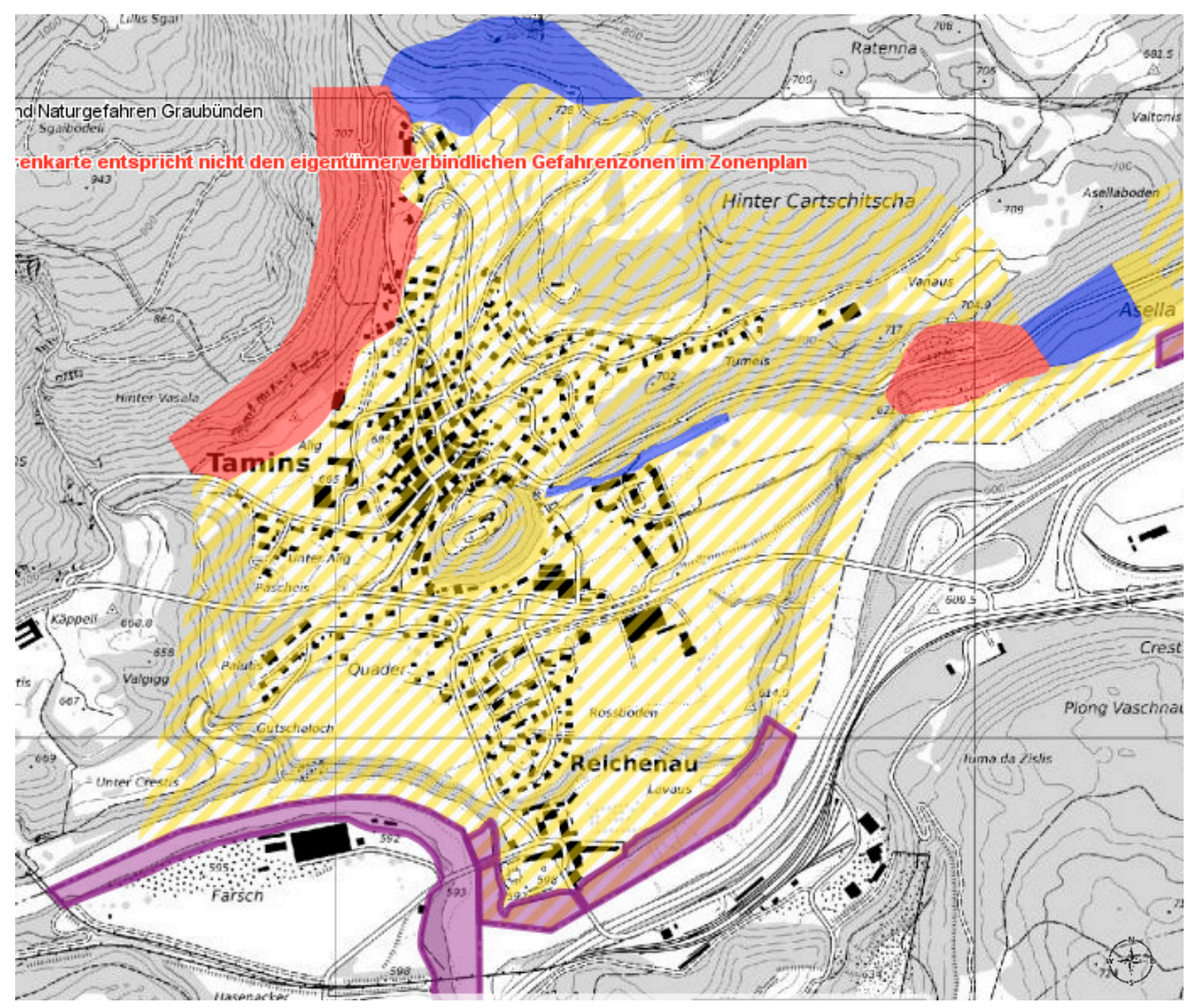

Figure 4. Natural hazard risk map of Tamins: rock fall risk zone (Latitude: 46.828093 । Longitude: 9.406315; (c) Canton of Grisons).

\subsubsection{Social Representations}

Results in the community of Tamins show that the population is less concerned with natural hazard risks. The interviewees, however, emphasized that the recent appearance of wolves was a big topic in the community. All private respondents showed concern and emotional responses due to the potential danger for livestock. Being less concerned with natural hazard risks, the interviewees in Tamins also showed less normative judgements. An exception was a community employee, who is a member of the crisis committee. In his eyes, the general population is not sufficiently aware of the rock fall risk along the nearby mountain pass.

Results on the social representation of danger confirmed the results in Felsberg and Domat-Ems that the interviewees are more concerned with danger and have more detailed thoughts about danger than about risk. Whereas a common reaction to the term risk is the expression that it is part of life, this is less the case with the term "danger". Danger is seen as a matter of experience and therefore of learning how to live with danger. In this, the meaning of "risk" rather merges the meaning of "danger". A single SR not shared by other interviewees in our study regions is related to surprise. Danger in contrast to risk in this respect is perceived as uncontrollable or unpredictable. 


\subsection{Communities Affected 10 Years Ago: Susch and Flims}

\subsubsection{Susch: Community Description}

The community of Susch is located at the banks of the Inn River (Figure 5), at the confluence of the Susasca river. Almost half of the community area lies in yellow or blue flood risk zones and severe floods are part of the local history. The most disastrous event remembered today took place in 1852, when several buildings were destroyed after a dam burst. In recent times, events within the last 15 years are remembered. The last severe event occurred in 2005, when heavy rainfalls caused severe flooding by the Susasca river.

The 2005 flood affected all inhabitants and made them collaborate to protect lives, clean up and restore buildings after the water subsided. Both officials and inhabitants reported that they were overwhelmed by the solidarity and proactive initiatives. The mayor emphasized that the momentum of cooperation was used to initiate other, non-natural hazard related projects for community development, for which approval could not be achieved before the event. As a reason for why the project could not be established before, diminishing trust and community spirit hindered earlier approval.

The flood event itself was efficiently handled, which was explained by strong personal connection between the members of the crisis committee, who are neighbours or relatives. Committee meetings are rather informal and responsibility is shared. Individual risk awareness and preparedness by the population is regarded as being of minor importance in daily life. It is only considered relevant for leisure time and sports.

Reliance on protection measures was interpreted as an indicator that risk awareness and responsible behaviour are decreasing in society. Therefore, increasing implementation of constructional measures is regarded ambivalently.

Respondents agree on the view that risk awareness rapidly diminishes after an immediate increase during a hazard event. This was observed not only among private citizens but also in municipality offices. The same counts for solidarity. The tendency to forget about hazard events is not only judged negatively, it is even regarded as unnecessary to make natural hazard risks an issue of permanent discussion. In terms of risk communication, this logic is also pointed out. The view is shared that information is consumed rather than absorbed and there is a tendency to ignore information if it is exaggerated. An example is exercises for warning signals, which are not taken seriously as they are only known for the purpose of practice and not emergency.

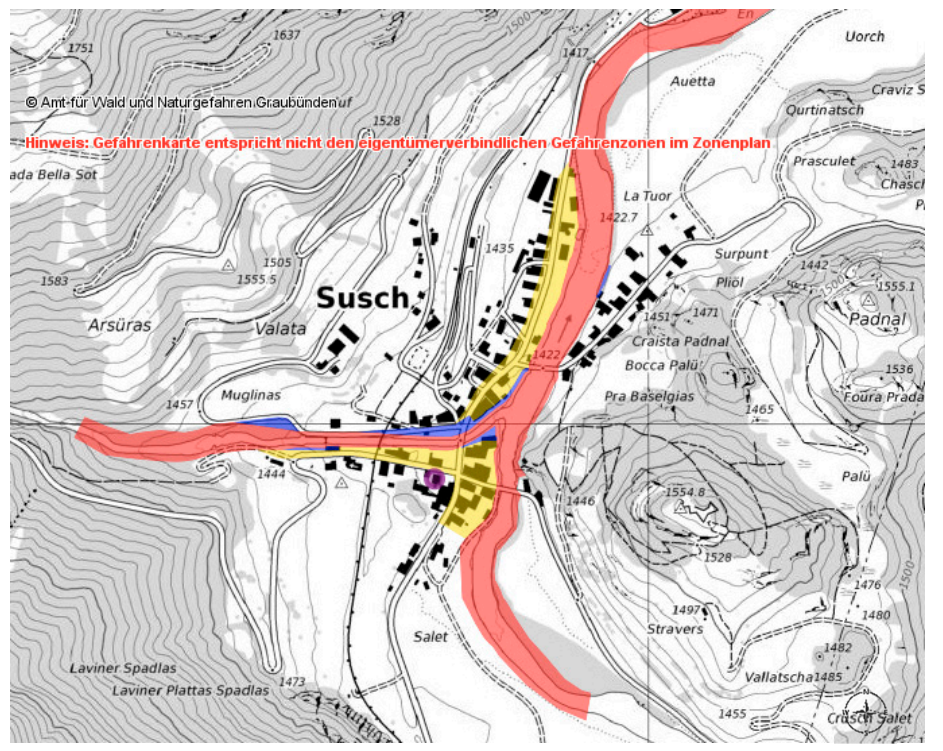

Figure 5. Natural hazard risk map of Susch: flood risk zones (Latitude: 46.750798 | Longitude: 10.079666; (C) Canton of Grisons). 


\subsubsection{Susch: Social Representations}

Similar to other communities, risk is predominantly understood as a natural hazard risk, in particular avalanches, floods and landslides. The local perspective on risks in Susch results in sharing social representations that fit circumstances and experiences distinct for the community. Interviewees who live on-site or officially are responsible for prevention of damage by natural hazards show a rather homogeneous view. Altogether, results on social representations of natural hazard risks in Susch cover four distinct dimensions:

One dimension is the meaning of risk as fate that cannot be influenced. This represents a rather passive attitude. It is similar to the understanding of risks as a part of life that needs to be accepted, however, the fatalistic view is more negatively and passively connoted. In contrast to this perspective is the attribution of risks as a catalyser for innovation. Compared to results in other communities, this is an exceptionally positive attribution of meaning. The positive attribution is due to the experience that risks can open the way to overcome previous structures that hinder progress. It can open the view for the need of change and innovation.

Apart from the fatalistic and progressive representation of risk, interviews in Susch also revealed representations of risks that are common for all communities in the case study. It is commonly shared understanding that risk in terms of leisure activities is a matter of individual responsibility. This is related to developing the ability to estimate conditions and make decisions based on adequate judgement and therefore learning. In Susch, however, learning from past experiences is not predominant. As interviews in Susch showed, social cohesion and solidarity are regarded as more important than learning from the past. History showed that structural measures that were implemented based on past experience and aimed to prevent similar damage from occurring again, did not help to prevent damage during the next event. The notion, according to the local circumstances of natural hazard risks in Susch, is more on conditions that allow a flexible reaction to unpredictable hazard processes and do not rely only on structural measures. A further dimension of SR of risk is grounded more on a universal than local perspective. Like interviewees in other communities who share such a universal perspective, risks are related to social change, global and ecological topics. Most of all, climate change is named as a cause of risk. Correspondingly, prevention of risks is interpreted as a matter of protecting nature. This indicates that such a view is related to reciprocal interpretation of human-nature relations.

Both terms, danger and risk, were mostly understood in respect of local natural hazard types. It is noticeable, that the term "danger", unlike "risk", did not evoke the association of individual responsibility or sports. The term "danger" is more related to caution. Generally, danger is regarded omnipresent and something one has to accept in mountain regions. In contrast to communities in the Imboden region, danger was less understood as threatening and not associated with expressions of fear or worry.

\subsubsection{Flims: Community Description}

The community of Flims is located at the feet of the Flims limestone, an unstable rock wall that is under permanent observation for rock fall (Figure 6).

The topic of risk management in Flims is, to a greater degree than in other communities within this study, influenced by the concern of raising fear among tourists. The community addresses risk prevention by providing budget for constructional measures, such as avalanche protection or river construction. During the winter season, natural hazard risk management is trusted to the regional tourism organisation White Arena.

Concerning risk communication to inhabitants, no initiatives are planned. Experts claim that concerns by inhabitants are not sufficiently regarded in local hazard risk management. Tourism is the communities' major topic. 
Regarding flood risk, the river was recently secured by construction measures, however there are concerns that the risk is beyond control by such measures. This is reported due to pressure from intense tourism.

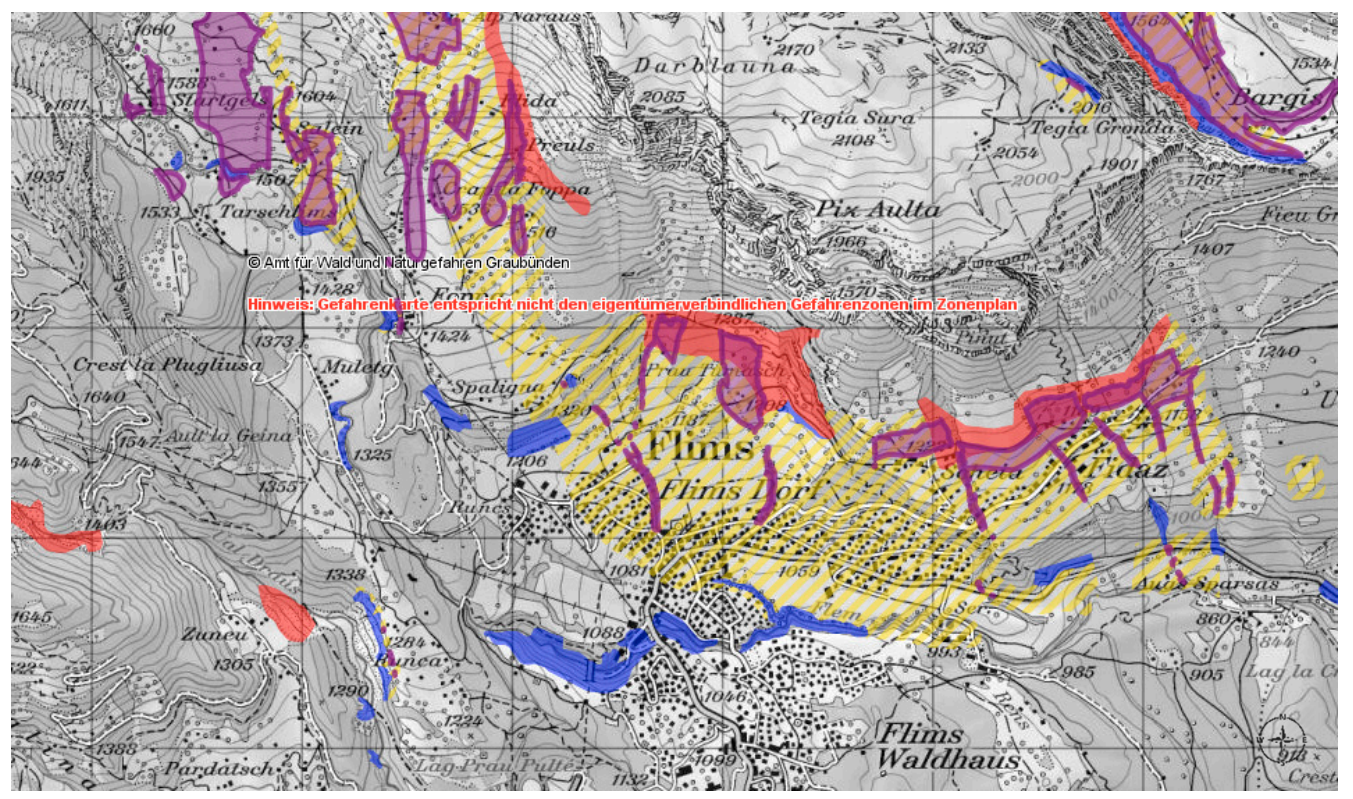

Figure 6. Natural hazard risk map of Flims: rock fall risk zones (Latitude: 46.836635 | Longitude: 9.284692).

\subsubsection{Flims: Social Representations}

Like in other communities that are exposed to frequent natural hazard events, risks are predominantly regarded to be natural hazard risks. The local perspective on risk is predominant and in a more general view, natural hazard risk is related to climate change.

Compared to the results in the other Imboden communities, social representations are more similar to those found in Felsberg, where citizens are visibly confronted with a steep rock face. Flims is a community in which historical hazard events as well as current threats are anchored in people's minds. This is also the case in Felsberg and Susch and goes along with the association of risk that it is an omnipresent part of life in a mountain region.

Flims in contrast to the other Imboden communities is a highly touristic location. Therefore, risks are also strongly regarded in the light of leisure time activities. In this respect, not only the association of risks as a potential threat is found in Flims. Risks are also perceived and used as a source of fun, adventure and identification by taking risks. As a new aspect, respondents in Flims expressed the association that risks are a matter of sticking to rules, that is, individual behaviour. The representation of risk as a source of adventure and opportunity to measure one's skills is related to learning and taking responsibility.

The topic of estimating and calculating rock fall risk, however, is understood contradictively. On the one hand risks are understood as controllable and calculable with scientific techniques, on the other hand the impossibility of calculating and controlling rock fall risk is highlighted. In contrast to other communities, both views are connoted with rather strong normative associations. It shows that the question of controllability is an important issue for the inhabitants of Flims.

Results on social representation of danger show that in the interviewees' minds there is little difference between danger and risk. Both are considered to be part of life in the mountains. Similarly, danger has a rather emotional connotation and risk is more associated with individual responsibility than danger. A difference compared to results in other communities is the notion of tourism, which is 
regarded as a source of danger as natural hazards get ignored with expanding tourism. Further, the belief in the controllability of damage by natural hazards is accompanied by doubt.

\subsection{A Touristic Community Scuol}

\subsubsection{Community Description}

The community of Scuol is the regional capital of the Inn region (Figure 7). In contrast to Susch, it is a highly frequented tourist town. The town has 5000 inhabitants and grows to more than 10,000 during the tourist season. Within the town area there are yellow risk zones around rivers and some blue risk zones due to flood and landslide risk. The community has not been affected by hazards for 30 years. Accordingly, both the population as well as the authorities don't consider natural hazards as a threat for the community. Natural hazard risk is mainly understood as avalanche risk in relation to tourism. The crisis committee in Scuol comprises 10 members and additional staff. However, there are no regular meetings or exercises. Cantonal activities concerning natural hazard risk management are hardly recognized or regarded.

It is assumed that an increase in frequency and severity of natural hazard events in the community area of Scuol can be expected. Yet, the reason for the lack of risk awareness is mainly explained by the rareness of events, while the difficulties in coordination and logistics are explained rather by diminishing community cohesion. Local associations and neighbourhood activities are joined less by the younger generation and individualism spreads instead.

Solidarity among inhabitants is considered to be linked to the size of affected areas and has an effect on the smoothness of coordination. In the case that a community as a whole is affected, solidarity is assumed high, as in the case of Susch.

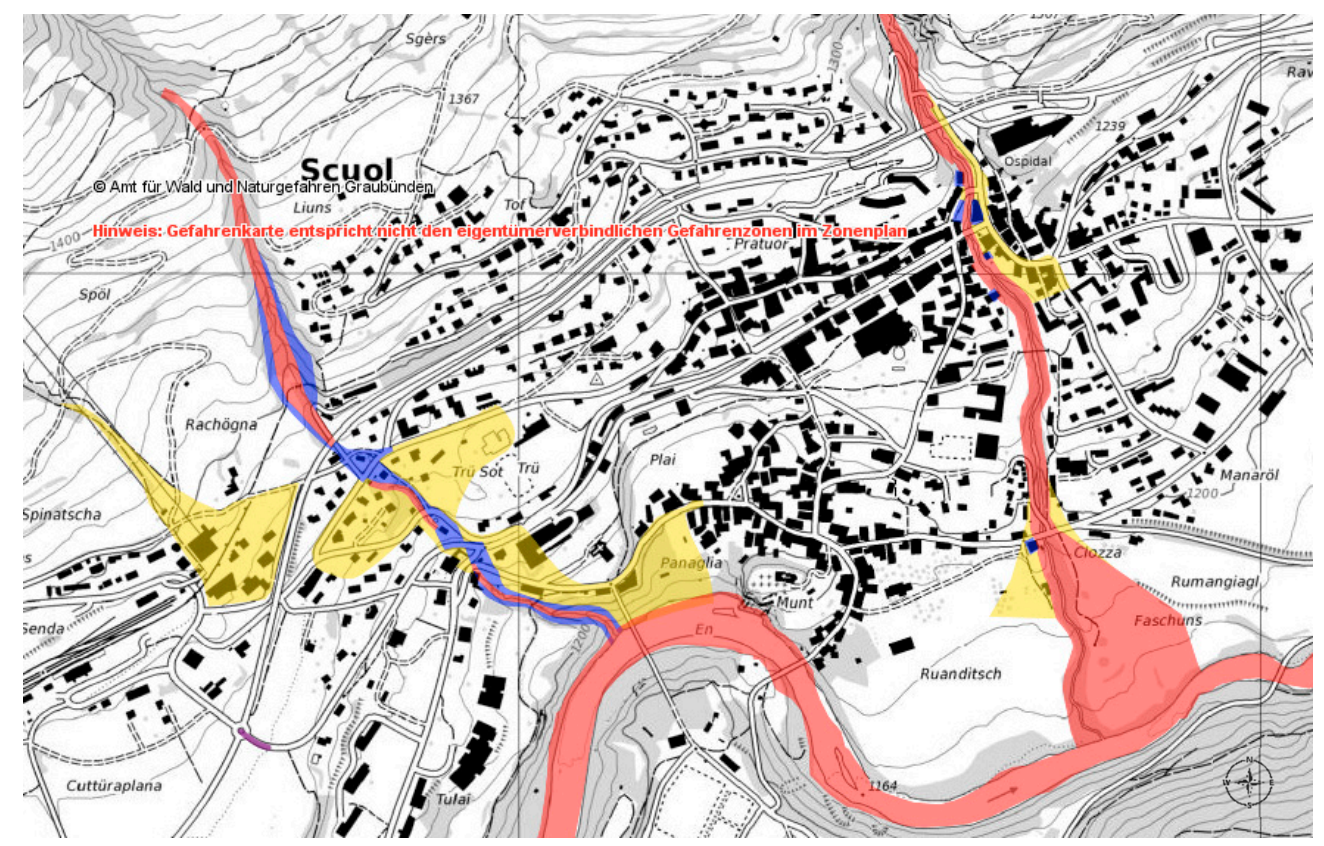

Figure 7. Natural hazard risk map of Scuol: flood risk zones (Latitude: 46.796872 | Longitude: 10.297738; (C) Canton of Grisons).

\subsubsection{Social Representations}

The influence of local conditions as a tourist destination is noticeable in social representations of risk in Scuol. Natural hazard risks are understood as individual leisure activity risks and consequently, risk behaviour is interpreted as individual estimation of avalanche warnings. This is also expressed in the normative component of the understanding of risks. 
The interviewees' representations of danger differ from the results on risk. Most noticeable is the emphasis on acceptance of danger. Further, danger is understood as related to natural hazard events rather than individual sports. Nevertheless, dealing with danger is regarded as an individual assessment and behaviour according to rules.

As in Felsberg and Susch, visitors were among the interviewees. All such cases showed that visitors' representations differ from those who are members of the local community.

\subsection{Aggregated Analysis over All Communities}

The inductive categories presented in the results section were analysed in aggregated form according to the most frequently named associations. Although this is not a quantitative survey, this semi-quantitative analysis provides an overview of results of all interviews. The results indicate, which meanings of risk and danger are distinct and which are overlapping. The core representations are given in Figure 8 and peripheral ones in Figure 9. The codes presented in Figures 8 and 9 show a particular pattern contrasting the main differences and overlaps common in people's understanding of "risk" and "danger". The term "risk" is understood as something that is strongly subject to human influence or decisions. Risks are regarded as a matter of individual responsibility and individual ability to make responsible decisions, for example, based on knowledge or skills.

In contrast to the core social representation of risk as something in control of individuals, the core social representation of danger is something to which one is passively exposed. The term danger, other than the term risk, evokes associations with natural hazard events and processes. In accordance with types of hazards that are relevant in local conditions, interviewees in communities affected by rock fall, primarily think of rock falls as a type of local danger. The term "danger" is more related to processes in nature on which humans have little influence and it is more associated as something threatening, that evokes emotions like fear. The term risk, in contrast to this emotionally connoted association, makes people think about measures to control risks and individual behaviour to expose oneself to risks, for example, a choice for risky sports. The comparison in terms of controllability shows that "risk" was more strongly associated with control than danger. This affirms the result of the communities of the Imboden region that with "risk" there is an emphasis on individual or general control, whereas with "danger" it is rather understood as a matter of natural power.

A further glance at overlapping categories shows that both are perceived as primarily related to natural hazards. Additional to local circumstances, is probably the case as far as interviewees knew about the topic of the study. However, "other risks" than natural hazard risks were also frequently named. In particular, several interviewees named traffic and single interviewees named food production, industry accidents, burglary, wolves, pests and neophytes.

In comprehension, the social representation of risk is primarily about individual choice and responsibility, whereas the core social representation of danger is a matter of a power that exceeds the sphere of human influence.

The overview given in Figure 9 particularly shows the scope of divergence in comparison of peripheral representations of risk and danger. As mentioned above, the periphery displays change in social representations. Abric [50] distinguishes between three kinds of change according to the strength of contradiction between old and new representations. In case of strong contradiction, the change is brutal, in case of mere incongruence the change is resistant but a process of justification and rationalization begins. The third kind of change is of progressive nature in the case that there is low contradiction. The single representation of risk as assessment, as well as the representation of danger as learning indicates such progressive change. 


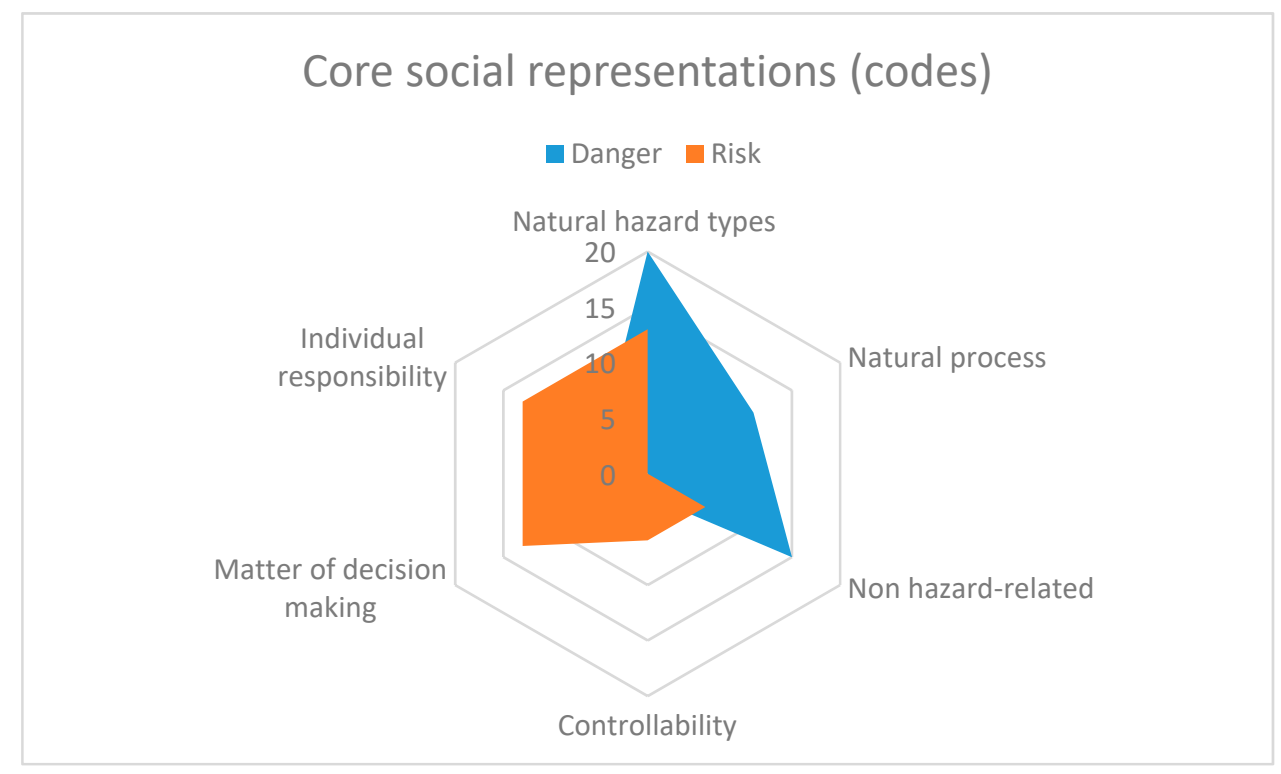

Figure 8. Core social representations of risk and danger ( $\geq 8$ namings).

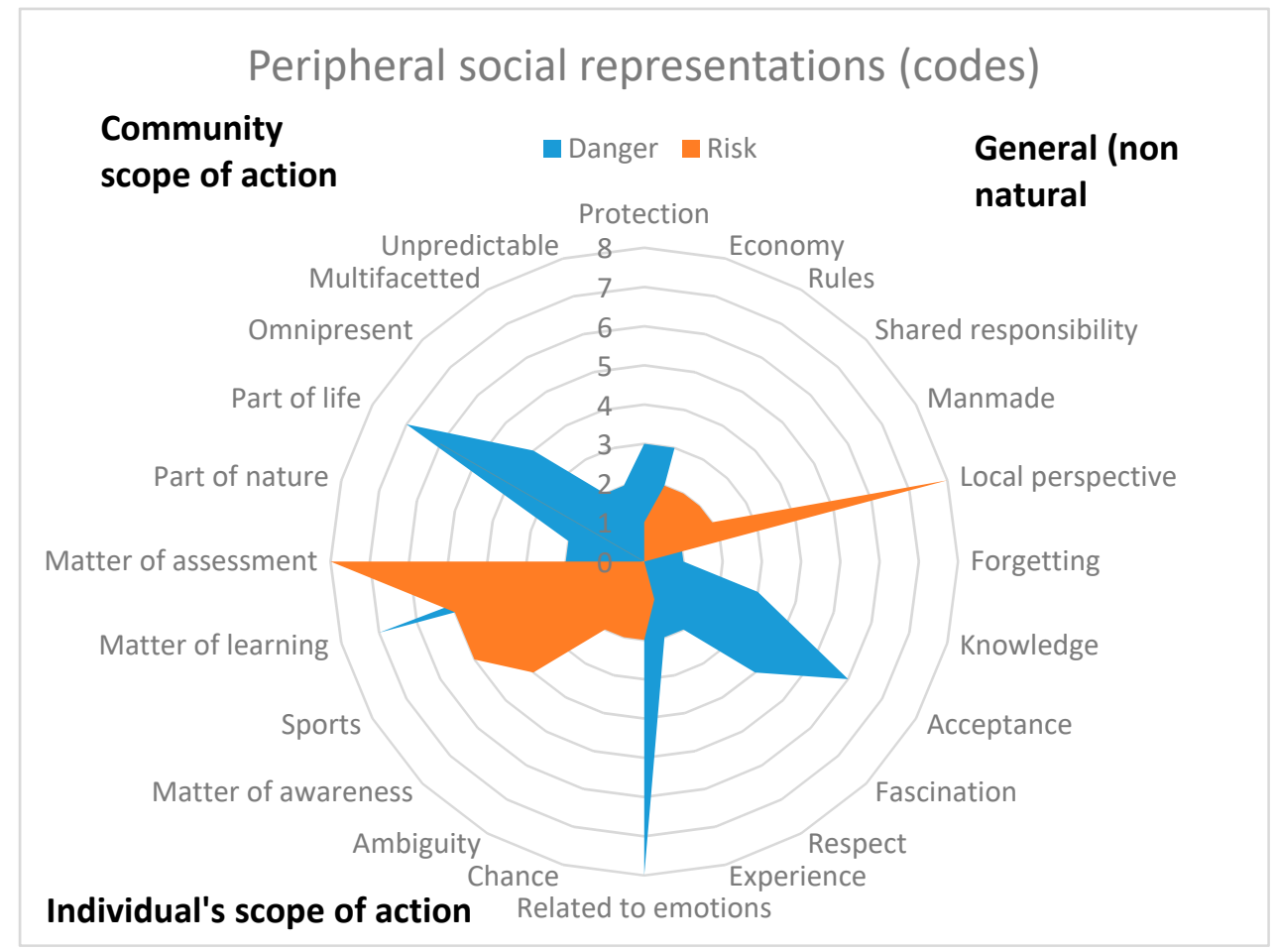

Figure 9. Peripheral social representations of risk and danger $(\leq 8$ namings, that is, the number of namings).

\section{Discussion}

\subsection{Risk and Danger}

The term danger is associated with threat, knowledge and acceptance, whereas the term risk refers to individual responsibility and rational decision-making. The clarity of the results show, in accordance with Schütz (2003), that in small communities, major meanings of aspects in everyday life are narrowly shared. It is noticeable that the two terms trigger different associations that are both important for the implementation of integrated risk management. Avoiding the term "danger" in risk communication, therefore, would evoke fewer desirable associations, meanings and believes. 
It further is important to consider that the meaning of risk can change. Representations at the periphery (Figure 8) offer potential explanations if the established core representations fail to provide sufficient explanations. They might become anchored in the collective consciousness or disappear, if not shared. These dynamics take place in everyday life and are shaped by the social structure in a community. As Moscovici [45] and Abric [50] describe, the process of meaning, knowledge and identity generation is also a process of in- and exclusion. According to this, results of SR of risk as a matter of individual responsibility can be interpreted in a twofold way. In one way, as an effect of the paradigm change toward integrated risk management, which is now observable in respondents' answers. In another way, the fact that this paradigm change occurs, can be interpreted as a bottom-up process: people's minds change and cause changes in risk management institutions and structures.

\subsection{The Local Perspective}

A distinct result is that local circumstances shape what meanings of risk and danger are shared. This result is similar to the result of Jurt's qualitative study on risk perception in South Tyrol, that showed risks are only regarded relevant if people are personally affected [1]. Inhabitants of communities that are regularly affected by natural hazard events associate the term risk closely with these events. For an inhabitant in the Inn region, natural hazards mean floods and avalanches, whereas in the Imboden region it means rock fall and landslides. In communities that are seldom affected by natural hazards, social representations of risk and danger are less related to natural hazards. It is the local environment that fills social representations of terms like risk or danger with particular meaning. Due to differences in local conditions, there are also differences in social representations.

In a more general perspective, climate change is the major association and regarded as a source of risk and danger. Accordingly, human interventions in nature and individual behaviour change towards a better balance, with nature appearing more important to the interviewees.

\subsection{Risk/Danger as Part of Life}

Most common is the view that risk or danger is part of life, especially in mountain regions. Although this social representation is widespread, the meaning can be very different. It can be understood as the readiness to accept residual risks; many interviewees are aware that there is no guarantee for absolute security, even if protection measures are implemented. The sentence that risk or danger is part of life can also express a fatalistic view, that is, that damage by natural hazards cannot or hardly be controlled or avoided.

Further, the view is related to identity. Many interviewees are proud to live in the mountains and live with natural hazards. It expresses a lifestyle that is closely connected to nature and also serves as demarcation from other lifestyles that appear to have lost this connection).

\subsection{Responsibility}

Risk and danger are synonymously understood in many respects. However, the aspect of responsibility shows differences. According to the interview results, people strongly associate risk as a matter of individual responsibility. It's the individual who decides whether to take risks or not, for example, in risky kinds of sports. The social representation of risk in terms of responsibility also revealed that making adequate decisions requires skills, knowledge and experience. People who lack such pre-requisites need to be protected and sensitized about risks they possibly take without being aware of it. This is also seen in the frequent view that risk is a matter of assessment. The social representation of risk as individual responsibility indicates that risk is subject to human influence. Risk is mainly understood as relative to individual behaviour, skills and knowledge.

In contrast, the social representation of danger stresses unpredictable, uncontrollable or invisible aspects. Consequently, human influence on danger is regarded as more limited. Danger is understood as something one encounters rather as a victim than as self-responsible actor. Consequently, danger 
turned out to be more emotionally connoted. None of the interviewees associated the term "risk" with fear or threat, as it was the case with the term "danger".

The public responsibility for protection from damage by natural hazards appeared mainly as distinct for interviewees who are professionally involved in risk management. Especially in communities where natural hazard events affect all inhabitants, prevention and protection are associated as tasks of the crisis committees. Accordingly, in communities where risks are associated with individual behaviour, this mainly refers to risky sports. The emphasis on individual responsibility does not contradict the view that protection from damage by natural hazards is regarded as a shared responsibility. This is in line with the finding that all actors in risk management are perceived as responsible in the Swiss population [24]. Unlike in the British context, a change of social contract to increase local responsibility seems not to be a main issue [61].

Content of public responsibility comprises surveillance and observation of critical areas, implementation of constructional protection measures, land use planning, organizing meetings and exercises by crisis committees. Risk communication and sensitization of the population are less commonly considered important, even though risk awareness and individual preparedness are generally estimated as rather low. An exception is the case of intense tourism, where the communication of natural hazard risk and land use planning can be in conflict with economic interest.

\subsection{Awareness and Collective Memory}

In all communities, awareness of natural hazard risk depended on the occurrence of natural hazard events. Only after such an event, especially when the community suffered severe damages, protection measures are taken. In this respect, no difference between professionals and laypersons was detected. Therefore, immediately after an event, chances are best for possible restructuration of local risk management, improvement of preparedness, for example, by implementation of protection measures or participation in continuing education for community officials.

It is considered natural that with time, after an event, collective memories and with these memories, risk awareness diminishes. The occurrence of natural hazard events in other, neighbouring communities appears to have no influence on taking measures in the own community, which seems to be a common phenomenon, captured in the research literature as the concept of unrealistic optimism. Interview results showed that media reports rather strengthen the impression that natural hazards are relevant elsewhere but not in the own community. This is also in line with Jurt's finding that risks are only regarded relevant if personal consequences are expectable [1]. Research literature suggest that the media have generally only limited influence on people's understanding of their everyday world: Familiar matters have been found to be subject to only limited susceptibility to influence by the (traditional) media [62] and media frames rather tend to contribute to the persistence of existing hazard understandings. Recent research furthermore revealed that social media affect people's long-term understanding of hazards [63] only marginally, while it can be very effective in case of emergent disasters, in particular if individuals are not able to access information from traditional media [64] or other sources.

It is further important to note that risk awareness not only referred to natural hazards. Depending on the community, other sources of risks, like industrial hazards or traffic are considered more relevant. Therefore, it is natural that past events are forgotten. In case of severe personal experience of damage or threat, reminders possibly awake traumatic experience.

The interviewees' memories in all communities refer to hazard events that occurred during the last 20 years and single historical events in the period of the last 200 years. For instance, in Flims, the destruction of a children's home by an avalanche in the 1930s is present in the collective memory. At the site, a memorial was built that reminds visitors and inhabitants of the rock fall event. Similarly, in Felsberg, the historical event from the mid-19th century is commonly remembered. In recent times, the memory reaches back 10 to 20 years as well. Further, in Susch, the destruction of parts of the village 
after a dam burst in the 19th century is remembered, whereas memories of more recent events do not go beyond the period of the last two decades.

\subsection{Solidarity and Social Inclusion}

Solidarity was commended in all municipalities during and after a natural hazard event. In exceptional situations, people are thrown out of their daily routines and quickly need to adjust to a dangerous situation and make the right decisions. In such a case, reliance on each other is crucial. As the case of Susch showed, a severe event can have profound influence on community life, which can be used as a source of momentum for innovative projects and motivating citizens to participate in community life. The experience of solidarity appears to increase trust into community leadership as well as neighbours. This relates to the view of social capital [65]. Trust in Susch turned out to be a resource for community development.

However, interviews also showed that community members who are well integrated and part of the personal network of crisis committee members, are thought about first. Inhabitants, who are less connected with the core group, however, appear to be disadvantaged.

The case of Susch showed that strong personal networks are a pre-condition for effective hazard risk management and mitigation of emergency situations. If actors are used to work together, know each other's competence and strengths, it makes immediate reaction more effective. Accordingly, the conclusion can be drawn that in case of weak networks, for example, in municipalities where the members of the crisis committee are not used to working together, this may hinder adequate immediate reaction.

\subsection{Notes for Communication}

According to Breakwell [11], the analysis of social representations can be used for the design of communication strategies. The result of the study shows that interviewees ascribed distinct meanings and beliefs to the term "risk" and "danger". In summary of the discussed results, risk is understood as a matter of individual responsibility that is controllable by taking measures and preparing for a possible event. Danger, in contrast, is regarded as an unpredictable, invisible possibility that humans are passively exposed to.

According to the typology of hegemonic, emancipated or polemical social representations of risk and danger are mostly of a hegemonic nature, that is, commonly shared core representations that were found in all case study communities (Figure 8). Emancipated representations are found at the periphery, that is, shared by fewer interviewees or distinct to certain communities. For instance, in the community of Domat-Ems that participated in the GRIP project, social representations were found that are distinct to the integrated risk management paradigm that was fostered with the GRIP project.

As the comparative analysis of social representations of risk and danger showed, the two terms evoke different associations. Most notably, risk is understood as individual responsibility and relative to behaviour and decisions, while it is not regarded as possible to prepare for danger, since a core understanding of danger is that it is not predictable.

Therefore, including both terms in risk communication might increase the range and attentiveness of addressees. The term risk does not serve well in raising emotions, whereas the term danger is more a term of daily life and more tangible for addressees, than the more abstract term risk.

As a strategy for risk communication, the term danger is suitable for connecting a particular message to daily life and thereby increasing relevance for the addressees. The term risk then is more suitable to communicate how danger can be reduced. As the mayor of Domat-Ems stated, risks that are known are not dangerous, while an event that was not considered possible or relevant has more potential to be dangerous. Altogether, interviewees moreover expressed attitudes of risk avoidance. However, at the innovative periphery of social representations, risk is also regarded as chance for individual, economic or social progress. 


\subsection{Limitations}

A limitation of the present study is that the results are inductively drawn from the interview material and therefore not strongly related to theory. The emphasis on presenting results rather descriptively is regarded important, so that the reader is invited to link the interpretation of the results according to her own theoretical considerations. A core value of the theory of social representations is to gain understanding of the range of meanings of risk and danger. How these meanings are thoroughly embedded into theoretical frames is beyond the scope of this article.

A further limitation is that a comprehensive presentation of the analysis of all interviews that allow deeper analysis on the level of individual interviews is not feasible. Therefore, the focus was put on the association part of the interviews and the presentation of original quotes from that part.

The value of the present study was to provide comprehensive results on social representations. It aimed to serve both research and practice in the reflection on methods in risk research and risk management. It provides an indication that future questionnaires should be carefully tested, for example, applying cognitive pre-testing, to gain more profound understanding of what is actually measured when terms like "risk" or "danger" are used in questionnaires or in risk communication to the population. The study, however does not provide representative findings.

\section{Conclusions}

Previous studies on risk awareness and preparedness showed that individual experiences, attitudes and perceptions have influence on the outcome of hazard risk preparedness. So far, in Switzerland no examination was conducted to find out what natural hazard risks actually meant to the general population as well as experts in local risk management.

The qualitative case study in the canton of Grisons showed that inhabitants in mountain villages share core social representations of risks and danger. The meanings and believes that are associated with the two terms overlap in the view that danger and risk are both omnipresent part of life. Especially the local perspective on life in the mountains showed that it requires experience and awareness of possible damage by natural hazards. Differences in social representations revealed that the term risk far more evokes the association with individual responsibility and behaviour, whereas the term "danger" is understood as something that is less controllable. The socially shared meaning of danger is that danger is in contrast to risk something not visible or calculable. The connotation with emotions, especially fear or threat is noticeably stronger than it is the case with the term "risk." For risk communication, it is therefore recommended to regard that both terms evoke distinct associations and feelings. This section is not mandatory but can be added to the manuscript if the discussion is unusually long or complex.

Author Contributions: E.M. conceived and conducted the research and M.B. was supervisor. In particular, E.M. designed the study, carried out the interviews, analysed data and drafted the manuscript. M.B. gave advice for the design and implementation for the study and substantially developed the draft.

Funding: This research was funded by the KULTURisk FP7-ENV-2010 project.

Acknowledgments: The authors thank their colleagues for continuing support and discussion, the officials from the Grisons Cantonal Office for Forest and Natural Hazards for enabling the study, especially Christian Wilhelm. Special thanks goes also to the interview partners. Further, the authors thank the reviewers for their constructive criticism in evaluating this paper. The study was financed in the frame of EU project KULTURisk.

Conflicts of Interest: The authors declare no conflict of interest.

\section{Appendix A}

Domat-Ems

R1C1_I1: municipal secretary

R1C1_I2: major

R1C1_I3: fire brigade commander

R1C1_I4: district forester 
R1C1_I5: hunter

Tamins

R1C2_I1: municipal secretary (m)

R1C2_I2: resident1 (f, farmer)

R1C2_I3: resident2 (f)

R1C2_I4: resident3 (m)

R1C2_I5: fire brigade commander ( $m$, member of local risk committee)

R1C2_I6: farmer1 ( $\mathrm{m}$ recent hazard experience, located at the edge of the village close to hazard zone)

R1C2_I7: district forester ( $m$, member of local risk committee)

R1C2_I5: farmer2 (m, sheep keeper, knows the surrounding well)

Flims

R1C3_I1: head of community construction office ( $\mathrm{m}$, in charge of community risk management)

R1C3_I2: restaurant owner $(\mathrm{m})$

R1C3_I3: merchant (m)

R1C3_I4: former fire brigade commander $(\mathrm{m})$

R1C3_I5: district forester ( $m$, member of local risk committee)

R1C3_I6: free rider $(\mathrm{m})$

R1C3_I7: deputy chief avalanche rescue (m)

Susch

R2C1_I1: visitor of local clinic (f)

R2C1_I2: resident (f)

R2C1_I3: municipal secretary (m)

R2C1_I4: hunter (m)

R2C1_I5: fire brigade commander (m)

R2C1_I6: major (m)

R2C1_I7: resident (f)

R2C1_I8: resident (m)

Scuol

R2C2_I1: employee tourist office (f)

R2C1_I2: civil protection officer ( $\mathrm{m}$, member of the local crisis committee)

R2C1_I3: resident (m)

R2C1_I4: tourist (f)

\section{References}

1. Joffe, H. Risk: From perception to social representation. Br. J. Soc. Psychol. 2003, 42, 55-73. [CrossRef] [PubMed]

2. Bubeck, P.; Botzen, W.J.W.; Aerts, J.C.J.H. A review of risk perceptions and other factors that influence flood mitigation behavior. Risk Anal. 2012, 32, 1481-1495. [CrossRef] [PubMed]

3. Kellens, W.; Terpstra, T.; de Maeyer, P. Perception and communication of flood risks: A systematic review of empirical research. Risk Anal. 2013, 33, 24-49. [CrossRef] [PubMed]

4. Kuhlicke, C.; Steinführer, A.; Begg, C.; Bianchizza, C.; Brundl, M.; Buchecker, M.; De Marchi, B.; Tarditti, M.D.; Hoppner, C.; Komac, B.; et al. Perspectives on social capacity building for natural hazards: Outlining an emerging field of research and practice in Europe. Environ. Sci. Policy 2011, 14, 804-814. [CrossRef]

5. Wachinger, G.; Renn, O.; Begg, C.; Kuhlicke, C. The risk perception paradox-implications for governance and communication of natural hazards. Risk Anal. 2013, 33, 1049-1065. [CrossRef]

6. Osberghaus, D. The determinants of private flood mitigation measures in Germany-Evidence from a nationwide survey. Ecol. Econ. 2015, 110, 36-50. [CrossRef] 
7. Thistlethwaite, J.; Henstra, D.; Brown, C.; Scott, D. How flood experience and risk perception influences protective actions and behaviours among Canadian homeowners. Environ. Manag. 2018, 61, 197-208. [CrossRef]

8. O'Neill, E.; Brereton, F.; Shahumyan, H.; Clinch, J.P. The impact of perceived flood exposure on flood-risk perception: The role of distance. Risk Anal. 2016, 36, 2158-2186. [CrossRef] [PubMed]

9. Aven, T. The risk concept-Historical and recent development trends. Reliab. Eng. Syst. Saf. 2012, 99, 33-44. [CrossRef]

10. Eiser, J.R.; Bostrom, A.; Burton, I.; Johnston, D.M.; McClure, J.; Paton, D.; van der Pligt, J.; White, M.P. Risk interpretation and action: A conceptual framework for responses to natural hazards. Int. J. Disaster Risk Reduct. 2012, 1, 5-16. [CrossRef]

11. Breakwell, G.M.; Barnett, J. The Impact of Social Amplification on Risk Communication; Contract Research Report 322/2001; HSE Books: Norwich, UK, 2001.

12. Jaspal, R.; Breakwell, G.M. Identity Process Theory: Identity, Social Action and Social Change; Cambridge University Press: Cambridge, UK, 2014.

13. Althaus, C.E. A disciplinary perspective on the epistemological status of risk. Risk Anal. 2005, 25, 567-588. [CrossRef] [PubMed]

14. Slovic, P.; Macgregor, D.; Kraus, N.N. Perception of risk from automobile safety defects. Accid. Anal. Prev. 1987, 19, 359-373. [CrossRef]

15. Slovic, P.; Finucane, M.L.; Peters, E.; MacGregor, D.G. Risk as analysis and risk as feelings: Some thoughts about affect, reason, risk, and rationality. Risk Anal. 2004, 24, 311-322. [CrossRef] [PubMed]

16. Gregg, C.E.; Houghton, B.F.; Johnston, D.M.; Paton, D.; Swanson, D.A. The perception of volcanic risk in Kona communities from Mauna Loa and Hualdlai volcanoes, Hawai'i. J. Volcanol. Geotherm. Res. 2004, 130, 179-196. [CrossRef]

17. Heitz, C.; Spaeter, S.; Auzet, A.V.; Glatron, S. Local stakeholders' perception of muddy flood risk and implications for management approaches: A case study in Alsace (France). Land Use Policy 2009, $26,443$. [CrossRef]

18. Gotham, K.F.; Lauve-Moon, K.; Powers, B. Risk and recovery: Understanding flood risk perceptions in a postdisaster city-The case of New Orleans. Sociol. Spectr. 2017, 37, 335-352. [CrossRef]

19. Douglas, M.; Wildavsky, A. Risk and Culture; University of California Press: Berkeley, CA, USA, 1982.

20. Tansey, J. Risk as politics, culture as power. J. Risk Res. 2004, 7, 17-32. [CrossRef]

21. Nathan, F. Risk perception, risk management and vulnerability to landslides in the hill slopes in the city of La Paz, Bolivia. A preliminary statement. Disasters 2008, 32, 337-357. [CrossRef] [PubMed]

22. Perri, F. What's in a frame? Social organization, risk perception and the sociology of knowledge. J. Risk Res. 2005, 8, 91-118.

23. Terpstra, T. Emotions, trust, and perceived risk: affective and cognitive routes to flood preparedness behavior. Risk Anal. 2011, 31, 1658-1675. [CrossRef]

24. Maidl, E.; Buchecker, M. Raising risk preparedness by flood risk communication. Nat. Hazards Earth Syst. Sci. 2015, 15, 1577-1595. [CrossRef]

25. Armas, I. Social vulnerability and seismic risk perception. Case study: The historic center of the Bucharest Municipality/Romania. Nat. Hazards 2008, 47, 397-410. [CrossRef]

26. Schoell, R.; Binder, C.R. System perspectives of experts and farmers regarding the role of livelihood assets in risk perception: Results from the structured mental model approach. Risk Analysis 2009, 29, $205-222$. [CrossRef] [PubMed]

27. Escobar, M.P.; Demeritt, D. Flooding and the framing of risk in British broadsheets, 1985-2010. Public Underst. Sci. 2012, 23, 454-471. [CrossRef] [PubMed]

28. Sherry, J.; Curtis, A. At the intersection of disaster risk and religion: Interpretations and responses to the threat of Tsho Rolpa glacial lake. Environ. Hazards-Hum. Policy Dimens. 2017, 16, 314-329. [CrossRef]

29. Lindell, M.K.; Perry, R.W. The protective action decision model: theoretical modifications and additional evidence. Risk Anal. 2012, 32, 616-632. [CrossRef] [PubMed]

30. Khan, S.; Mishra, J.L.; Lin, K.H.E.; Doyle, E.E.H. Rethinking communication in risk interpretation and action. Nat. Hazards 2017, 88, 1709-1726. [CrossRef]

31. Kolkman, M.J.; van der Veen, A.; Geurts, P.A.T.M. Controversies in water management: Frames and mental models. Environ. Impact Assess. Rev. 2007, 27, 685-706. [CrossRef] 
32. PLANAT: Sicherheit vor Naturgefahren-Vision and Strategie. 2014. Available online: http:/ /www.planat.ch/ fileadmin/PLANAT/planat_pdf/alle_2012/2001-2005/PLANAT_2004_-_Sicherheit_vor_Naturgefahren.pdf (accessed on 18 December 2018).

33. Siegrist, M.; Gutscher, H. Flooding risks: A comparison of lay people's perceptions and expert's assessments in Switzerland. Risk Anal. 2006, 26, 971-979. [CrossRef] [PubMed]

34. Siegrist, M.; Gutscher, H. Natural hazards and motivation for mitigation behaviour: People cannot predict the affect evoked by a severe flood. Risk Anal. 2008, 28, 771-778. [CrossRef]

35. Schutz, A.; Luckmann, T. The Structures of the Life-World; Northwestern University Press: Evanston, IL, USA, 1973.

36. Heeb, J.; Hindenlang, K. Negotiating landscapes in the Swiss Alps. Experiences with implementation of a systemic landscape development approach. Mt. Res. Dev. 2008, 28, 105-109. [CrossRef]

37. Biggs, D.; Abel, N.; Knight, A.T.; Leitch, A.; Langston, A.; Ban, N.C. The implementation crisis in conservation planning: Could "mental models" help? Conserv. Lett. 2011, 4, 169-183. [CrossRef]

38. Dooley, D.; Catalano, R.; Mishra, S.; Serxner, S. Earthquake preparedness-Predictors in a community survey. J. Appl. Soc. Psychol. 1992, 22, 451-470. [CrossRef]

39. Brennan, M.; O'Neill, E.; Brereton, F.; Dreoni, I.; Shahumyan, H. Exploring the spatial dimension of community-level flood risk perception: A cognitive mapping approach. Environ. Hazards 2016, 15, 279-310. [CrossRef]

40. Lau, D.C.; Murnighan, J.K. Demographic diversity and faultlines: The compositional dynamics of organizational groups. Acad. Manag. Rev. 1998, 23, 325-340. [CrossRef]

41. Garmendia, E.; Stagl, S. Public participation for sustainability and social learning: Concepts and lessons from three case studies in Europe. Ecol. Econ. 2010, 69, 1712-1722. [CrossRef]

42. de Vente, J.; Reed, M.S.; Stringer, L.C.; Valente, S.; Newig, J. How does the context and design of participatory decision making processes affect their outcomes? Evidence from sustainable land management in global drylands. Ecol. Soc. 2016, 21. [CrossRef]

43. Höppner, C.; Whittle, R.; Brundl, M.; Buchecker, M. Linking social capacities and risk communication in Europe: A gap between theory and practice? Nat. Hazards 2012, 64, 1753-1778. [CrossRef]

44. Ramsbottom, A.; O’Brien, E.; Ciotti, L.; Takacs, J. Enablers and barriers to community engagement in public health emergency preparedness: A literature review. J. Commun. Health 2018, 43, 412-420. [CrossRef]

45. Moscovici, S. The phenomenon of social representations. In Social Representations_Explorations in Social Psychology; Moscovici, S., Duveen, G., Eds.; New York University Press: New York, NY, USA, 2001.

46. Demeritt, D.; Nobert, S. Models of best practice in flood risk communication and management. Environ. Hazards-Hum. Policy Dimens. 2014, 13, 313-328. [CrossRef]

47. Halbwachs, M. Das kollektive Gedächtnis; Suhrkamp Verlag: Berlin, Germany, 1985.

48. Durkheim, E. Rules of Sociological Method; Free Press: Rockland, ME, USA, 1982.

49. Wagner, W. Social representation theory. In Encyclopedia of Peace Psychology; Christie, D.J., Ed.; Wiley-Blackwell: Malden, MA, USA, 2012.

50. Abric, J.-C. A Structural Approach to Social Representations. In Representations of the Social: Bridging Theoretical Traditions; Deaux, K., Philogene, G., Eds.; Wiley-Blackwell: Hoboken, NJ, USA, 2001; pp. $42-47$.

51. Beck, U. Risikogesellschaft-Auf dem Weg in eine andere Moderne; Suhrkamp: Frankfurt am Main, Germany, 1986.

52. Husserl, E. The Crisis of the European Sciences and Transcendental Phenomenology; Northwestern University Press: Evanston, IL, USA, 1970.

53. van Manen, M. Researching Lived Experience: Human Science for an Action Sensitive Pedagogy; Althouse Press: London, ON, Canada, 1990.

54. Glaser, B.G.; Strauss, A. The Discovery of Grounded Theory: Strategies for Qualitative Research; Routledge: London, UK, 1999.

55. Yin, R.K. Case Study Research. Design and Methods; Sage: Thousand Oaks, CA, USA, 2003.

56. Raetzo, H.; Lateltin, O.; Bollinger, D.; Tripet, J. Hazard assessment in Switzerland-Codes of practice for mass movements. Bull. Eng. Geol. Environ. 2002, 61, 263-268.

57. Building Insurance Grison (GVG). Jahresbericht 2014 Gebäudeversicherung Graubünden GVG. 2015. Available online: http:/ / www.gvg.gr.ch/data/downloads/file_1_626.pdf (accessed on 18 December 2018). 
58. Mayring, P. Qualitative Inhaltsanalyse-Grundlagen und Techniken, 8th ed.; UTB Beltz Verlag: Stuttgart, Germany, 2002.

59. Meyers, M.D.; Newman, M. The qualitative interview in IS research: Examining the craft. Inf. Organ. 2007, 17, 2-26. [CrossRef]

60. Felsberg. Available online: http://www.boehmgeol.ch/72-0-Felsberg.html (accessed on 18 December 2018).

61. Adger, W.N.; Barnett, J.; Brown, K.; Marshall, N.; O'Brien, K. Cultural dimensions of climate change impacts and adaptation. Nat. Clim. Chang. 2013, 3, 112-117. [CrossRef]

62. Entman, R.M. Democracy without Citizens: Media and the Decay of American Politics; Oxford University Press: New York, NY, USA, 1989.

63. Tang, Z.H.; Zhang, L.G.; Xu, F.H.; Vo, H. Examining the role of social media in California's drought risk management in 2014. Nat. Hazards 2015, 79, 171-193. [CrossRef]

64. Choi, D.H.; Yoo, W.; Noh, G.Y.; Park, K. The impact of social media on risk perceptions during the MERS outbreak in South Korea. Comput. Hum. Behav. 2017, 72, 422-431. [CrossRef]

65. Putnam, R.D. Bowling Alone: Collapse and Revival of the American Community; Simon \& Schuster: New York, NY, USA, 2001.

(C) 2018 by the authors. Licensee MDPI, Basel, Switzerland. This article is an open access article distributed under the terms and conditions of the Creative Commons Attribution (CC BY) license (http:/ / creativecommons.org/licenses/by/4.0/). 